\title{
Nascimento de um Projeto: Pressupostos
}

Na verdade, em arte não existem problemas dos quais a obra de arte não seja a suficiente solução.

(André Gide)

Teste primeiro capítulo, gostaria de apresentar uma série de ques1 tões que nortearam a consolidação desta pesquisa como processo criativo. Por isso, o leitor encontrará diversas conjugações de verbos como começar, iniciar e nascer, já que o objetivo principal é narrar o "antes" de um projeto que iniciou (eis o anunciado) na intuição empírica.

Além disso, os conceitos estudados, e a ordem na qual aparecem, procuram orientar o leitor por uma lógica de pensamento que evidencia a busca de um ator que sempre encontrou, na academia, um espaço para a discussão e a reflexão de seus processos artísticos, mas que acredita firmemente na premissa de André Gide que aparece como epígrafe deste capítulo. Assim, a reflexão teórica que preenche esse ponto de partida deve ser observada como plataforma de um projeto cujo propósito principal é a experimentação cênica, e não somente a reflexão a partir da acumulação de ideias abstratas.

Para garantir a execução dessas intenções, a seguir, apresentam-se o relato da experiência prévia que sustenta este projeto de pesquisa e a exposição dos principais conceitos que servem como seu eixo teórico. 


\section{Tudo começa no palco}

O projeto $O$ ator em solidão nasceu da minha experiência em 2010, quando trabalhei como ator no monólogo La navidad de Harry. A encenação era baseada na peça Harry's Christmas, do dramaturgo, ator e diretor inglês Steven Berkoff, a partir da tradução feita pelo ator colombiano Juan Ignacio Vieira e sob a direção do também colombiano Carlos Bolívar.

A peça conta a história de Harry, um homem próximo a fazer quarenta anos, que se encontra sozinho no Natal. Durante cinco dias, ele está à espera de uma ligação ou de um cartão de Natal que faça com que acredite que alguém pensa nele nesse período. Infelizmente, a noite de Natal chega, e Harry não recebe o esperado. A peça é composta de situações que vão do cômico ao trágico, mantendo constantemente o drama de um homem que não consegue se relacionar com o mundo ao seu redor.

No início da minha carreira, a ideia de fazer uma peça teatral na qual eu fosse o único ator era uma possibilidade longínqua e correspondia a uma fascinação pelo trabalho de outros atores. A mestria daqueles indivíduos que atuavam nos solos, e que me fascinavam, quase sempre representada no sustento de carreiras de longa data, fazia com que um projeto dessa categoria fosse constantemente adiado, alimentado pelo medo de ser um ator menos experiente.

Essa ideia permanecia fixa na minha mente devido às lembranças de belos trabalhos que acabaram, inclusive, me estimulando a escolher a profissão de ator. Uma destas é o trabalho da atriz colombiana Nora Quintero. Ainda no ensino básico, assisti a seu Monólogo para una actriz triste, espetáculo que estreou em Medellín em 1986 (eu assisti vários anos depois), cujo texto foi escrito pelo dramaturgo colombiano José Manuel Freidel especialmente para a atriz. Nora já era uma atriz bastante experiente naquela época e uma mulher carregada de uma sensibilidade muito especial. Seu espetáculo falava de crises pessoais e se desenvolvia entre a realidade da atriz e a infinidade de personagens interpretadas na sua carreira. Como jovem espectador de teatro e aspirante a ator, o solo de Quintero me fazia pensar em um futuro distante no qual seria eu o que faria esse grande solo e resumiria, no palco, uma carreira cheia de experiências. 
Tive uma sensação parecida em 2006 quando assisti ao espetáculo solo da grande atriz argentina Norma Leandro, intitulado Sobre el amor y otros cuentos sobre el amor. O espetáculo era praticamente o resumo de uma grande carreira. A atriz transitava por todos os estados emocionais possíveis e passava de uma história a outra com uma mestria impressionante. Para minha surpresa, Norma assinava como dramaturga, diretora e atriz da peça.

Esses e outros espetáculos fizeram com que eu acabasse construindo uma ideia de solo que só seria possível depois de uma carreira mais consolidada. No entanto, as circunstâncias que me levaram a fazer a peça de Steven Berkoff foram mais fortes do que o receio inicial.

Formei-me em Arte Dramática na Universidad de Antioquia, na cidade de Medellín (Colômbia). Muito antes de concluir meus estudos de graduação, tive a sorte de consolidar uma equipe de trabalho, da qual nasceu o grupo Íntimo Teatro ${ }^{1}$. Além disso, trabalhei em várias produções do Teatro El Tablado ${ }^{2}$ e com outros grupos da cidade.

Ainda contando a experiência nos outros grupos, Íntimo Teatro foi o primeiro em que tive um trabalho profissional de vários anos como ator e, depois da universidade, minha maior escola de formação. Seu diretor artístico, Carlos Bolívar, foi meu professor na Escola de Teatro da Universidad de Antioquia e é a quem devo o conhecimento da técnica das ações transformadoras de Jorge Eines, sobre a qual aprofundei nos meus exercícios interpretativos. A técnica de Eines define o trabalho do ator a partir da interpretação do texto dramático e considera a ação física como um elemento transformador da cena, fazendo com que o trabalho do ator seja resultado da interação com seus colegas de cena em um intercâmbio constante de "transformações".

1 O grupo Íntimo Teatro nasceu em Medellín em 1997, por iniciativa do diretor colombiano Carlos Bolívar, e dissolveu-se em 2007. Durante aqueles anos, foram encenadas oito peças teatrais, das quais participei como ator em cinco (Noches de amor efimero, Locos de amor, Palabras encandenadas, El inevitable destino de Rosa de la Noche e Casi una diosa) e, como diretor, em uma (El juego).

2 Teatro El Tablado é um grupo que começou em 1983 sob a direção de Mario Yepes Londoño e, depois de um recesso de vários anos, retomou atividades e continua produzindo até agora. Trabalhei como ator de forma intermitente 
As peças que trabalhei nesse grupo foram de diferentes gêneros e estavam baseadas no trabalho dos atores como elemento principal da cena. Uma das últimas, Palabras encadenadas (Figura 1), na qual a ação é desenvolvida o tempo inteiro com a atriz colombiana Gloria Montoya, que sempre me acompanhou em cena, foi fundamental para entender realmente a transformação de minha função como ator a partir do trabalho do outro.

Figura 1. Palabras encadenadas. Íntimo Teatro. Dramaturgia: Jordi Galcerán. Direção: Carlos Bolívar e Gloria Berrío. Atuação: Gloria Montoya e Juan David González Betancur (2001)

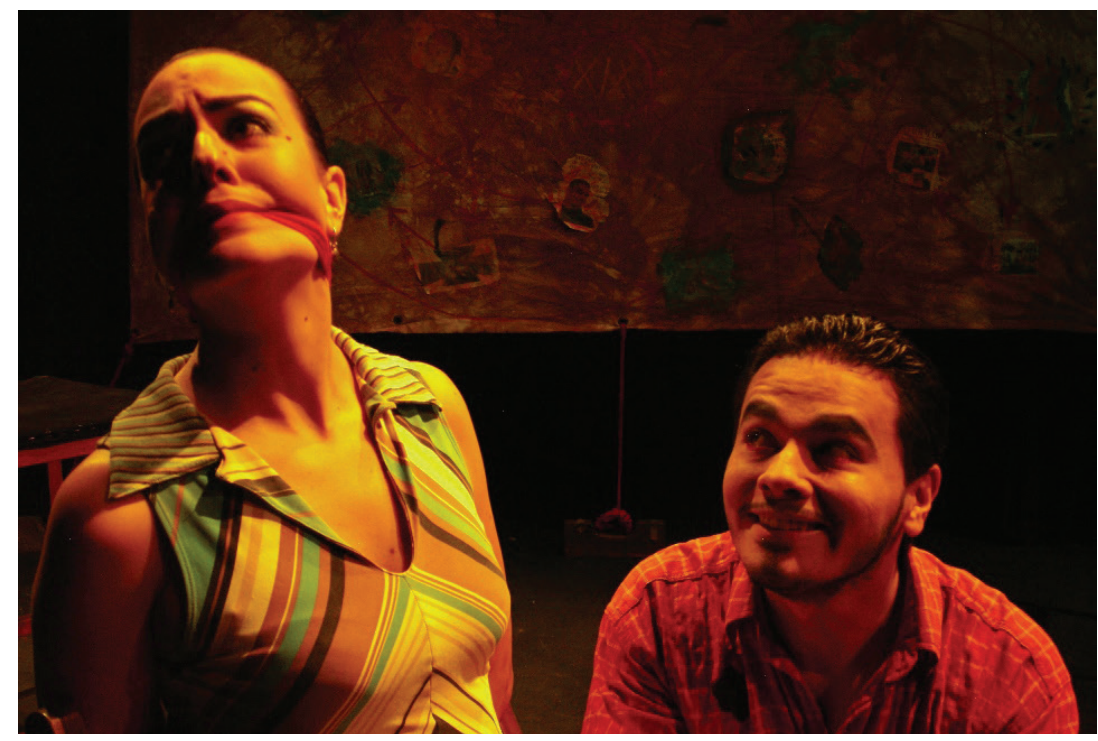

Fotografia: Jaime Usma.

Voltando às circunstâncias da aparição de La navidad de Harry (Figura 2) no meu processo, em 2004, mudei-me para Bogotá (Colômbia). Nessa cidade, durante os primeiros anos, participei de alguns processos com outros grupos de teatro, mas não consegui fazer o tipo de trabalho que eu queria. Por isso, em 2009, comecei a procurar atores com a ideia de consolidar um novo coletivo teatral. A empresa não deu certo e fiquei

nas peças Abelardo y Eloísa, Terror y miserias del Tercer Reich, La historia del zoo e Cenicienta. 
sem poder iniciar nenhum projeto teatral durante vários meses devido a diferenças estéticas e dificuldades financeiras, entre outros motivos. Sem a possibilidade de conseguir uma equipe de trabalho, a solução que encontrei foi a criação de um espetáculo solo.

Inicialmente, pensei em procurar uma peça dramatúrgica escrita para um único ator e encená-la, mas tudo indicava que, como intérprete, não poderia fazer isso sem a ajuda de um diretor. Por conta disso, acabei convidando o diretor com quem eu já tinha trabalhado em outros momentos. Sugeri-lhe vários textos; porém, dada a necessidade de uma afinidade mais próxima com os seus interesses, ele acabou me propondo a peça de Berkoff.

Figura 2. La navidad de Harry. TODAvía Teatro. Dramaturgia: Steven Berkoff. Direção: Carlos Bolívar. Atuação: Juan David González Betancur (2010)

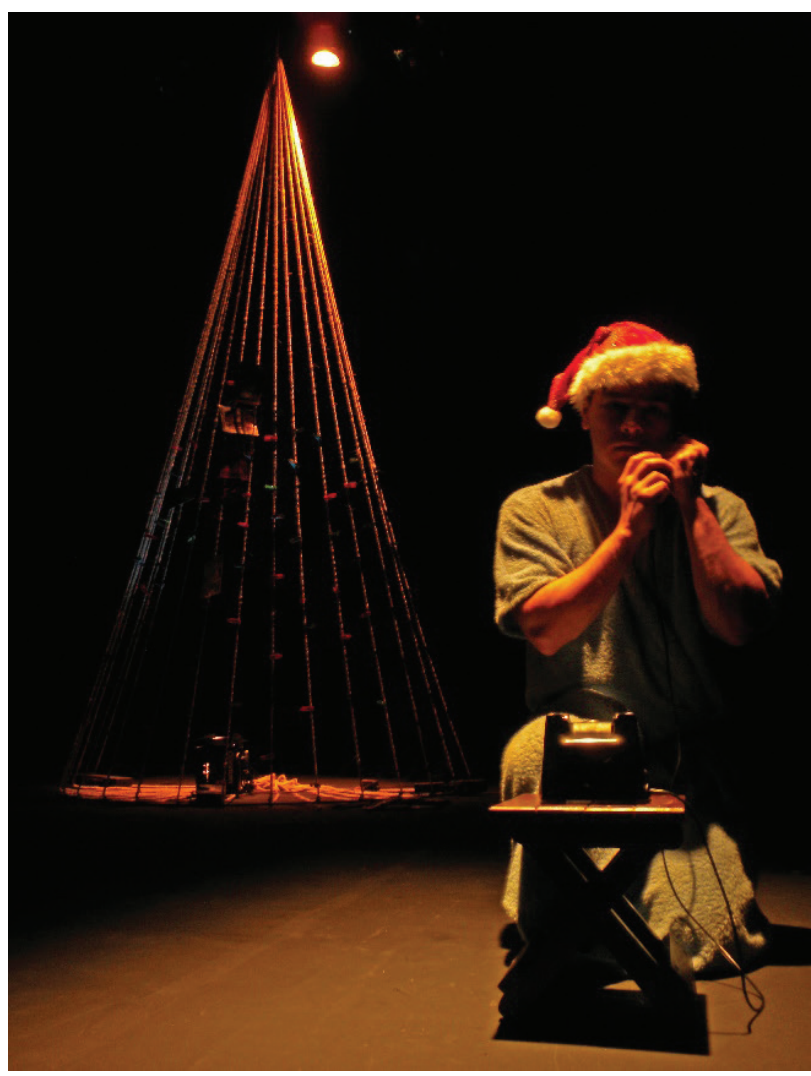

Fotografia: Jaime Usma. 
A montagem representou para mim um grande desafio e, devido à impossibilidade daquela época de trabalhar com outros atores, aceitei sem hesitar. Em muitos casos, esse tipo de espetáculos acaba sendo produzido em circunstâncias parecidas. No caso de La navidad de Harry, uma resenha feita por Matilde Salazar Ospina fez referência a esse aspecto.

Em um país onde o fazer artístico é um desafio, onde os esforços por realizar montagens cênicas são assumidos por artistas independentes que acreditam no seu fazer, destaca-se a coragem de encenar peças unipessoais. No caso de La navidad de Harry, é um esforço notável que contribui à compreensão do sujeito a partir do teatro. (2011, p. 153, tradução minha)

Nessa crítica, a expressão artistas independentes evidencia as circunstâncias narradas acima e coloca o solo em um panorama que parece ser recorrente na visão externa que se tem da produção desse tipo de espetáculos eventos. Renato Ferracini (2014) corrobora esse fato quando afirma: "[s]eria demasiado simplista relacionar a alta produção de solos (também chamados monólogos) somente à questão da falta de verbas, dificuldades financeiras ou ainda a uma negação ao conceito de companhias" (p. 2). No texto A performance solo como engrenagens de memórias e coletividades, do qual foi extraída a citação anterior, Ferracini (2014) assinala que essa visão faz com que os solos sejam considerados um tipo de produção menor:

[...] se os solos podem ser considerados uma produção menor, ou gerados somente em relação a uma falta de verba ou ao esvaziamento da produção de companhias, estabelecemos uma hierarquia de produtividade: as grandes produções fomentadas e patrocinadas e/ou os espetáculos de grupos consagrados seriam considerados os espetáculos "sérios", efetivos, relevantes esteticamente, enquanto os solos seriam somente frutos de uma crise financeira, estética e do modo de produção espetacular. Essa visão tacanha sobre uma produção relevante como os solos oblitera um pensamento mais 
verticalizado sobre suas funções estéticas, sociológicas, antropológicas e ontológicas. (p. 2)

Embora essa primeira experiência com o solo tenha sido produto de um tipo de "crise", parecida com a relatada pelo autor, ela se converteu no germe de uma proposta estética que reconhece todas essas qualidades e permitiu-me vislumbrar a potencialidade desse tipo de espetáculo.

Quando a montagem começou, soube logo que a experiência ia ser difícil. O exercício criativo que conhecia demandava a companhia de outros atores, mas, naquele instante, estava sozinho em cena. Ninguém estava no palco para me "transformar" e eu não tinha ninguém naquele cenário para "transformar". Ainda assim, o diretor não me exigiu nada muito diferente do que já tinha feito em montagens anteriores e "apliquei" a técnica que já conhecia. Como ator, mantive-me em ofício vivo e consegui fazer duas temporadas com sucesso e algumas apresentações particulares.

No entanto, a presença do diretor, que mora quase o tempo todo na Espanha, deu-se exclusivamente durante a etapa de criação da peça, enquanto a de divulgação e dos ajustes posteriores ficaram sob minha responsabilidade. Isso fez com que eu assumisse grande parte do processo sozinho. A sensação de ter que assumir a solidão do processo produziu um diálogo interior constante. Cada decisão que implicava uma nova circunstância, uma pequena ou grande mudança ou uma adaptação física de conteúdo da peça abonou a confiança na ideia de trabalhar autonomamente. Sem o diretor e começando a experimentar a possibilidade de "trair" o texto (timidamente ainda, a nossa versão mudou o contexto da história e desistiu de algumas referências do original), a iniciativa de fazer daquela situação uma pesquisa criativa mais longa chegou quase por abdução ${ }^{3}$.

3 Ao falar de abdução, parto do conceito proposto por Thomas A. Sebeok e Jean Umiker-Sebeok (2004). Eles refletem sobre "esse singular instinto de suposição", ao qual Charles S. Peirce se refere mais comumente como $a b d u$ ção ou retrodução. A abdução recebe várias significações no trabalho deles. Falam dela como o primeiro degrau do raciocínio científico, como o único tipo de argumento que inicia uma nova ideia ou como instinto que confia na 
Como ponto de partida, aquela fascinação pelo monólogo e a experiência de chegar ao palco sozinho, por circunstâncias iniciais externas ao trabalho artístico, não pareciam ser suficientes para justificar que aquilo poderia se tornar uma pesquisa artística e acadêmica. Só tinha a intuição e as projeções que estavam em minha mente para acreditar em que isso fosse possível. Nesse panorama, a aparição do conceito de $a b d u c ̧ a ̃ o$ foi fundamental para validar esse tipo de conhecimento intuitivo no campo científico como elemento inspirador. A esse respeito, Umberto Eco (1989) assinala que “o raciocínio por Abdução é típico de todas as descobertas científicas 'revolucionárias”” (p. 161).

Esse conceito é de vital importância para um projeto que procura respostas a partir da prática artística, contribuindo com um componente sensual ao pensamento investigativo (Sebeok e Umiker-Sebeok, 2004). Longe já dos temores iniciais, posso afirmar que a ideia inicial desta pesquisa chegou comandada por uma espécie de instinto natural que aparentemente não tinha nenhum fundamento racional. Ao contrário do que eu acreditava, Peirce descreve a abdução como um instinto racional e enfatiza, ao mesmo tempo, sua natureza racional e instintiva (Bacha, 1998). Foi em meio a essa revelação que pensei que a solidão, um elemento aparentemente inócuo, não seria, a partir daí, uma solução, mas sim uma nova maneira de entender meu trabalho como ator ${ }^{4}$.

A questão, então, era definir um sistema de trabalho artístico em que o ator realizasse um exercício de criação autônoma sem ter que

percepção inconsciente das conexões entre os aspectos do mundo. A abdução, no fim das contas, nada mais é que conjetura ou intuição.

4 De fato, meu processo de criação se alimenta constantemente desse instinto que, embora tenha ganhado lugar de validade na lógica científica atual, já era elemento natural da lógica artística. Por abdução, chegaram muitas das ideias que se materializaram depois na encenação. A partir de uma conversa, por meio de uma imagem que arbitrariamente suscita outra ou simplesmente como a aparição de um pensamento que esclarece fora de ensaio um problema que não se solucionou dentro dele; esse tipo de "revelações" é parte importante do que fica como elemento de criação cênica. Assim, se a abdução bem pode explicar a chegada daquela ideia que suscitou esta pesquisa, ela também pode explicar muito da construção do exercício cênico prático. 
passar pela intervenção de uma voz externa (de um diretor ou de um dramaturgo) que transforma seu papel de intérprete. Acostumado como eu estava a investir em uma técnica que relaciona o trabalho do ator com a tarefa de representar as intenções do autor do texto teatral, por meio da orientação do diretor cênico, a solidão que experimentei fazendo a peça de Berkoff me convidou a me liberar ainda mais.

Por isso, quando eu decidi fazer La navidad de Harry, tive a necessidade de pensar de novo sobre o que o ator faz no palco. Pensei em um ator contemporâneo que pode prescindir dos outros papéis tradicionais das artes cênicas e ter a autonomia de outros artistas. Um ator que não depende de um diretor nem de um texto dramatúrgico anterior para fazer seu trabalho em cena. O mesmo Berkoff foi motivo de inspiração para esse projeto. Ele é reconhecido como ator, diretor e dramaturgo, sendo que, em algumas das suas produções, assume os três papéis. Assim o apresenta Lúcia Romano (2008):

[c]om mais de sessenta anos de carreira, Berkoff atua, escreve e dirige, sendo comparado a autores-diretores da importância de Bob Wilson, Elizabeth LeCompte e Peter Sellars, a encenadores-coreógrafos como Richard Foreman, Emily Mann e Maria Irene Fornes e a performers como Lindsay Kemp — dançarino, diretor e mímico. (p. 110)

Romano também assinala como a criação dramatúrgica de Berkoff está intimamente ligada ao trabalho de atuação, direção e produção. "Este cruzamento de funções é resultado da sua prática teatral, multidisciplinar e sempre autoral, à maneira das formas teatrais centradas no ator, como a commedia dell'arte, e dos grandes atores-empresários, como Kean e Oliver" (Romano, 2008, p. 116). Eis a grande inspiração que constituiu o teatrista inglês para a projeção de um possível espetáculo no qual eu pudesse experimentar esse tipo de multidisciplinaridade.

A minha primeira ideia (veremos nos próximos capítulos como isso mudou conforme avançou a pesquisa) tratava-se de um espetáculo solo construído a partir da adaptação de um romance de André Gide, O imoralista, publicado em 1902. O processo de encenação contemplava as etapas tradicionais do fazer teatral: ainda assumindo 
todas as funções criativas, começava na dramaturgia e acabava com o trabalho de interpretação do texto. Contudo, a pesquisa foi me revelando que este não seria o caminho a seguir. Além disso, os objetos de inspiração da encenação foram se ampliando, fato que envolveu outras peças do mesmo autor e algumas referências não literárias e de minha experiência pessoal.

O que ficou claro é que estava assumindo um processo de criação artística no qual prevalecia a necessidade de ser o autor da cena e não mais só um intérprete. Esse ponto esclareceu ainda mais o projeto e completou o título da pesquisa: $O$ ator em solidão: passagem de intérprete a autor da cena na criação de um espetáculo unipessoal. Dessa maneira, a proposta poderia se resumir como um projeto de pesquisa teórico-prática que procura respostas ao trabalho criativo de um ator que prescinde de outras figuras comuns na tradição teatral, como o diretor ou o dramaturgo, para atingir a categoria de ator-autor e encontra, na situação de solidão, uma ferramenta de trabalho sobre as possibilidades criativas desse ator que tem, em sua própria experiência, os materiais para conseguir sair do ato habitual da interpretação.

As perguntas que surgiram dessa aproximação inicial, então, foram: que espetáculo me interessa criar? O que eu entendo como interpretação e autoria no teatro? Que tipo de ator é o que assumiria um processo como esse? Como aproveitar a solidão e que tipo de solidão seria essa na criação de um espetáculo, sendo o teatro em si mesmo uma experiência coletiva por excelência? Essas questões como elementos teóricos prévios são apresentadas a seguir.

\section{Monólogo, solo ou espetáculo unipessoal?}

Que tipo de espetáculo eu farei? Foi a primeira pergunta que apareceu. Parecia uma obviedade que seria um monólogo. Se o meu interesse era ser autor do meu próprio trabalho e não apenas intérprete, a resposta natural era levar até o limite a solidão que produziu La navidad de Harry.

Até aqui, o leitor terá notado o uso indiscriminado de expressões como monólogo, solo e espetáculo unipessoal para se referir mais ou 
menos à mesma experiência. $\mathrm{O}$ motivo dessa multiplicidade de nominações guarda uma estreita relação com uma confusão de conceitos que também foi parte do processo que se apresenta nesta pesquisa. A partir de agora, esse esclarecimento deixará de ser adiado.

A palavra monólogo é o termo comum para chamar os espetáculos que têm um só ator em cena, no entanto sempre associada ao discurso verbal. Por esse motivo, é insuficiente para determinar o tipo de espetáculo que poderia sair desse tipo de experimentações, tendo termos aparentemente mais amplos, como o usado habitualmente no Brasil — solo— ou o que ganhou força nos últimos anos na língua espanhola —obra unipersonal (espetáculo unipessoal)— ${ }^{5}$.

Patrice Pavis (2001) entende o monólogo teatral ${ }^{6}$ como um discurso de uma personagem que não está dirigido a um interlocutor. Como forma discursiva, o monólogo é habitualmente usado no mesmo sentido do termo solilóquio ${ }^{7}$. Assim o confirma o Dicionário do

5 A pesquisadora argentina Nerida Dip corrobora essa afirmação. Sua dissertação de mestrado, intitulada Espetáculo solo, fragmentação da noção de grupo e a contemporaneidade (2005), foi publicada posteriormente em uma versão em espanhol intitulada Solo en la escena (2010). Nesta última, traduz o termo solo como unipersonal. Lembre-se que a palavra solo se traduziria literalmente do espanhol como só ou sozinho. Embora considere mais adequado o termo espetáculo unipessoal para definir a proposta desta pesquisa, cita-se aqui a dissertação, dado que a versão em espanhol não oferece nenhuma revisão dos conceitos.

6 É importante esclarecer que o termo será usado só na sua acepção teatral e não na associada à literatura, na qual falaríamos de um tipo de narração que foca o relato a partir do mundo interior de uma personagem. Isso também para evitar, por um lado, discussões geradas por fórmulas realistas que consideram a ausência de um interlocutor dentro da ficção cênica como um assunto de inverossimilhança e, por outro, a polêmica sobre a relação personagem-espectador, sendo este último o interlocutor óbvio da encenação. Recomenda-se, para seguir essa discussão, o primeiro capítulo da dissertação de mestrado de Nerida Raquel Dip (2005), citada neste livro. Também não se pretende entrar na polêmica entre monólogo e dialogismo porque, como diz Anne Ubersfeld (2005), “[a] palavra teatral é, mesmo no monólogo, essencialmente dialogada” (p. 178).

7 Pavis (2001) o considera uma das formas do monólogo teatral e não um sinônimo. "O solilóquio, ainda mais que o monólogo, refere-se a uma situação na qual a personagem medita sobre sua situação psicológica e moral, 
teatro brasileiro quando, no verbete monólogo, assinala que "[o]s tratadistas teatrais não estabelecem claramente rígidas diferenças entre monólogo e solilóquio" (Guinsburg, Faria e Alves, 2006, p. 187, itálico no original). Simultaneamente, o verbete solilóquio se define como "[s]inônimo de monólogo" (Guinsburg, Faria e Alves, 2006, p. 279, itálico no original). Contudo, a definição desse dicionário corrobora a associação do monólogo com a produção verbal:

[...] trata-se de um texto dramático a cargo de um só intérprete no palco. Pode ser a parte de uma peça - e nesse caso o termo solilóquio também é apropriado - , ou uma peça inteira, geralmente não muito longa, que pode ser implícita ou explicitamente dirigida ao público. (Guinsburg, Faria e Alves, 2006, p. 187, itálico no original)

Comparando as definições dos dois dicionários (o do teatro brasileiro e o de Pavis), o termo monólogo pode ser definido do panorama da ficção ou do panorama da cena. A proposta de Pavis estaria marcada pelas intenções da personagem (trata-se de um indivíduo que, por circunstâncias particulares, se encontra falando sozinho), o que corresponderia com o panorama da ficção; enquanto a definição de Guinsburg, Faria e Alves coloca o monólogo como um assunto da cena (só vemos um ator no palco). A esses dois termos, valeria a pena somar outro que, mesmo não sendo tão popular, é relevante para estabelecer as diferentes ênfases que acabam dando forma às definições: monodrama. Segundo Manuel García Gómez (2007), o monodrama se diferencia do monólogo na ideia da presença de um só ator em cena, independentemente da participação de um número particular de personagens. Nesse sentido, o monodrama permite a aparição de múltiplos personagens e discursos, mas todos eles comandados por um só ator no palco. Essa terceira categoria coincide com a proposta do Dicionário do teatro brasileiro e foca o assunto como uma questão 
da cena. Além disso, monólogo e monodrama coincidem em centrar a questão na presença de um só indivíduo (ator ou personagem); contudo, ao levar em conta a etimologia que dá forma a esses termos, o primeiro está associado ao discurso (a palavra), enquanto o segundo, à ação. Em ambos os casos, a nominação acaba sendo insuficiente para definir o que esta pesquisa se propõe.

Continuando com a exploração de termos associados ao conceito de monólogo teatral, a pesquisadora Nerida Raquel Dip apresenta várias formas cênicas monologáveis à luz da autora argentina Beatriz Trastoy: o recital, o monodrama, o melólogo, o one-man/woman-show e o espetáculo solo.

O recital consiste na apresentação de um ator, músico ou dançarino que interpreta monólogos ou poemas. O monodrama é uma obra estruturada na forma de um monólogo, em que as personagens e situações que o constituem são apresentados [sic] do ponto de vista de uma personagem só, que é a que aparece na cena. O melólogo é um gênero que mistura música e monólogo, e que apareceu, pela primeira vez na América Latina, no Río de la Plata no século XVIII. O one-man/woman-show é uma forma espetacular que se originou no music-hall onde uma personagem monologa e apresenta sketchs, canções, danças e imitações, ou seja, que permite um comparsa de apoio. Finalmente, o espetáculo solo [...] Para Trastoy o espetáculo solo é um formato espetacular onde com frequência o ator assume funções de dramaturgo e diretor. (Dip, 2005, p. 29)

Nessa ordem de ideias, a última das definições, correspondente ao espetáculo solo, seria a mais adequada para os interesses desta pesquisa. No entanto, além dessa especificidade, pouco se fala sobre o termo específico para o teatro. Ferracini, por exemplo, não o diferencia de monólogo. No primeiro fragmento de seu artigo A performance solo como engrenagens de memórias e coletividades, citado acima, fala de solos e coloca entre parênteses a frase "também chamados monólogos", o que confirma que, na prática, a reflexão sobre esses conceitos não ocupa um lugar determinante. 
O termo solo parece ser muito mais comum nas áreas de música e de dança. Uma rápida consulta no dicionário de língua portuguesa Aurélio demonstra a existência apenas de duas acepções relacionadas com a arte: "[t]recho musical executado por uma só voz ou um só instrumento" ou "[b]ailado executado por uma só pessoa" (Ferreira, 2010, p. 708). No mesmo sentido de monólogo, solo pode fazer referência tanto ao todo quanto à parte de uma peça musical ou de dança. Além disso, as definições apresentadas fazem ênfase em um assunto que não pode passar inadvertido: a execução. $\mathrm{O}$ assunto no campo da dança e da música não tem a ver com a presença de um só intérprete em cena, como acontece no terreno do teatro. Refere-se ao fato de concentrar a execução da peça, ou de uma de suas partes, em um indivíduo só. Nesse caso, por exemplo, o solo em dança e em música pode se dar com a presença completa da companhia ou da orquestra.

Pelo apresentado no parágrafo anterior, o termo usual na língua espanhola é mais específico. Por um lado, ao falar de espetáculo unipessoal, a ideia de totalidade fica mais definida. Por outro, o adjetivo unipessoal pode ser mais inclusivo no sentido de contemplar assuntos como criação e proposta estética, além da simples execução. Esses argumentos constituem o motivo pelo qual eu decido, a partir deste momento, usar esse conceito. Agora, voltando à definição dessa experiência para o teatro, Dip (2005) diz:

[...] este tipo de obra é o resultado de um processo de escritura diferente do modelo convencional. Os espetáculos solos são escritos, na maioria das vezes, pelo próprio ator que também assume o papel de diretor. Isso diz respeito a uma auto-absorção das funções no mesmo ator, o que, definitivamente, nos conecta com o novo sujeito trabalhador, que aspira a prescindir dos outros para executar suas obras, e, ao final, seus desejos.

Sabemos que num texto teatral escrito da forma convencional, isto é, escrito separadamente da cena, as rubricas têm a função de ser a greta por onde o autor (que não é o ator) expõe suas indicações interpretativas; porém no espetáculo solo estas indicações provêm do próprio ator. Assim, o ator deixa de ser o intermediário 
da vontade de um ser que se encontra ausente no ato da representação; o ator não materializa a vontade de outro, mas permite-se desempenhar a expressão de sua própria vontade na materialização da encenação. (p. 33)

Seguindo a proposta de Dip, aparentemente, o espetáculo solo contribui para a libertação do ator da figura do dramaturgo, o que, segundo ela, potencializa a aparição de novas narrações que quebram os paradigmas dos textos clássicos da literatura.

É possível pensar que no momento em que o ator ocupa o lugar de dramaturgo e absorve suas funções, pode-se perder o caráter coletivo do discurso cênico. É provável que isto fragilize a dimensão política do espetáculo. É um dos perigos maiores da auto-absorção, mas, ao mesmo tempo, a distância entre quem cria o texto e quem o emite diminui, e isso reforça o caráter mais genuíno na relação ator/espectador. A mediação é menos significativa junto à função da representação. (Dip, 2005, p. 34)

Para os interesses desta pesquisa, o fragmento anterior é de grande utilidade para entender as potencialidades do espetáculo unipessoal, independentemente de seus alcances dramatúrgicos, enquanto experiência comunicativa. No entanto, esta pesquisa discorda de algumas asseverações feitas pela pesquisadora argentina. Entre elas, a afirmação de que o unipessoal fragiliza a dimensão política do espetáculo. Isso se conecta também com outra das infelizes conclusões da citada dissertação: “[...] o solo é um formato cênico que reflete as origens da história até mesmo em períodos anteriores, pois se trata de um ato expressivo individual que nasce da separação do coletivo" (Dip, 2005, p. 126).

Nesse ponto, retorno ao pesquisador brasileiro Renato Ferracini, que oferece uma visão contrária do assunto e é quem me permitirá vislumbrar mais claramente essas potencialidades que convidam a me aproximar à forma do espetáculo unipessoal. Para começar, a fórmula Solo = Coletivo com que conclui o já mencionado artigo A performance solo como engrenagens de memórias e coletividades 
marca uma perspectiva completamente diferente. Como coordenador do Lume ${ }^{8}$, o pesquisador afirma que, dentro do grupo, os solos são momentos de respiro de criação e experiências únicas dos atores que permitem a coesão do coletivo.

Cada ator do LUME deve aprender a ser um coletivo mesmo em sua singularidade e o solo, como já disse, é um espaço excepcional para esse "teste" estético. Cada ator do LUME deve treinar a capacidade de composição e, portanto, de contaminação. E qual lugar mais perigoso e solitário que um espetáculo solo para colocar essa questão em sua liminaridade? É assim que o LUME vê o solo: um lugar de experiências de limite no qual a positividade paradoxal singular/coletivo deve estar em plena discussão cênica. E aqui apresento ainda outro paradoxo: no LUME são os espetáculos solos que proporcionam a possibilidade de convivermos e criarmos coletivamente. Acreditamos que estar em grupo é ser singular e plural, homogêneo e heterogêneo ao mesmo tempo. É viver essa postura crítica de trabalho estético no cotidiano e no extracotidiano, na sala do escritório e na sala de trabalho. (Ferracini, 2014, p. 4)

Sob essa perspectiva, o unipessoal não necessariamente nasce do afastamento do coletivo, como afirma Nerida Dip. Nesse caso, é a partir do fortalecimento da singularidade que se afiançam as tramas que dão solidez ao coletivo ${ }^{9}$. Mas, sem importar sua função dentro da estrutura de grupo —esta pesquisa não se situa nesse contexto-, a argumentação de Ferracini é de especial relevância na medida em que relativiza a

8 “O Lume — Núcleo Interdisciplinar de Pesquisas Teatrais —, criado em 1985 pelo ator, diretor e pesquisador Luís Otávio Burnier, juntamente com os atores Carlos Alberto Simioni e Ricardo Puccetti e a musicista Denise Garcia, vem, desde sua fundação pesquisando, elaborando, codificando e sistematizando técnicas não interpretativas de representação para o ator. [...] A meta de seus trabalhos é o estudo e aprofundamento de métodos que permitam a elaboração e codificação de uma técnica pessoal para a arte do ator" (Ferracini, 2001, p. 31).

9 É interessante ver como o autor, pesquisador por anos do trabalho de grupo, concede relevância à questão individual. Em outra das suas publicações, 
distância que, geralmente, se considera inacessível entre singularidade e coletividade. Entendida a primeira como afastamento, sua proposta enfatiza o desejo de particularizar e compartilhar a experiência individual como uma das grandes potencialidades do espetáculo unipessoal, o que coincide perfeitamente com minha intenção estética atual.

Falo [...] do espetáculo solo como espaço de experimentação plena para o atuante. É nele que se pode observar, para além da busca do experimento único e específico e da procura da autonomia da expressão, todo um campo de experiência no qual o atuante pode coletivizar uma singularidade. A pergunta de como ir da experiência única e autônoma de criação para uma zona estética de contaminação coletiva é a grande potência estética que o solo proporciona. (Ferracini, 2014, p. 4)

$\mathrm{Na}$ busca de um ator (note-se que Ferracini prefere o termo atuante) que pretenda assumir as funções outorgadas ao diretor e ao dramaturgo com o interesse fundamental de potenciar suas possibilidades autorais a partir da encenação de um espetáculo unipessoal, as palavras do coordenador do Lume resultam mais que justificativas. Corrobora-se, então, esse tipo de espetáculo como terreno fértil para a experimentação e a exploração da singularidade, sejam quais forem os objetivos externos à sua própria existência estética.

\section{Da interpretação à autoria}

A passagem que esta pesquisa se propõe considera como ponto inicial uma abordagem do trabalho do ator, a qual pode explicar muito bem meu percurso profissional até o momento que começou essa indagação, e a que espera chegar ao estágio da autoria. A palavra que melhor pode

assinala: “[...] os grupos não são eternos e, em geral, os indivíduos sobrevivem aos grupos” (Ferracini, 2013, p. 157). 
definir esse ponto de partida é interpretação, que se entende como a função tradicional do ator ocidental ${ }^{10}$. A seguir, indagarei o conceito e farei algumas referências históricas nesse sentido. Em seguida, esclarecerei a acepção de autoria que me interessa.

\section{O ator como intérprete}

Uma das perguntas que me fiz quando eu comecei a definir os interesses de meu projeto de pesquisa foi: se a interpretação não é a única função do ator, quais outras aparecem nesse panorama? Para resolver a questão, é importante aclarar particularmente o que se entende por interpretação no universo do ator. Para esses esclarecimentos, o trabalho iniciado por Luís Otávio Burnier (2009) e continuado por Renato Ferracini (2001; 2013) nos servirá de guia.

$\mathrm{Na}$ busca de uma "representação não interpretativa”, Burnier oferece as bases do que definirá como ator-intérprete (ele fala realmente de ator que interpreta). $\mathrm{O}$ assunto começa a ser discutido a partir da acepção dos verbos interpretar e representar.

Em seu sentido próprio, interpretar quer dizer traduzir, e representar significa "estar em lugar de" (o chefe do gabinete que representa o prefeito), mas também pode significar o encontro de um equivalente. Assim, quando um ator interpreta um personagem, ele está realizando a tradução de uma linguagem literária para a cênica; quando ele representa, está encontrando um equivalente. (Burnier, 2009, p. 21, itálico no original)

A busca, tanto de Burnier quanto de Ferracini, é motivada pela ideia de um ator que não interpreta. Em contrapartida, Burnier fala do ator que representa. Trata-se de um ator que não procura uma personagem já existente, mas constrói um equivalente por meio de suas ações físicas,

10 A especificidade do universo ocidental se determina no sentido de que aqui não se indaga pelas funções do ator no Oriente, não só pela extensão que isso demandaria, mas também pela minha realidade contextual. 
seu principal material de trabalho. Assim, de novo por oposição, Burnier (2009) enfatiza a relação entre o ator-intérprete e o texto dramático.

Todo intérprete é um intermediário, alguém que está entre. No caso do teatro, ele está entre o personagem e o espectador, portanto entre algo que é ficção e alguém real e material. A noção do intérprete tem suas raízes na literatura dramática. O texto propõe o personagem, que é interpretado pelo ator. (p. 22, itálico no original)

Nesse sentido, o ator-intérprete seria uma espécie de tradutor das propostas do escritor. Como tradutor, o ator-intérprete seria um intermediário entre o dramaturgo e o espectador, afirmação corroborada por Ferracini (2001): "A interpretação está intimamente relacionada com o texto dramático. O intérprete funciona como um tradutor do texto em cena e todos os dados e informações para construção da sua personagem são retirados do texto e/ou em função deste" (p. 45, itálico no original).

O ator que representa, então, não depende do texto dramático para sua criação. Seguindo essa lógica, Ferracini (2001) afirma que, quando não interpreta, o ator cria a partir de si mesmo: "Assim, sem informações preliminares ou dados para a construção de sua personagem, ele necessita operacionalizar uma maneira nova de construção de sua arte" (p. 45-46). Eis a questão-chave da proposta de Burnier e de Ferracini. Torna-se fundamental para os interesses da minha pesquisa entender que a saída da interpretação abre a possibilidade de potenciar a exploração da minha singularidade como espaço de criação autoral. Os resultados das pesquisas desses criadores me dão licença para me colocar como um ator não interpretativo.

No Ocidente, os atores a quem chamamos de não interpretativos, salvo em algumas técnicas aculturadas como a mímica Decroix e o balé clássico, não se utilizam de um processo de aculturação forçado, imposto de fora, mas tentam buscar, dentro de si, os mecanismos que os levem a essa maneira particular de utilização corpórea e enérgica da cena, criando uma técnica pessoal de representação. (Ferracini, 2001, p. 47, itálico no original) 
Sobre os procedimentos pessoais que uso na minha criação cênica, falarei nos seguintes capítulos. Por enquanto, a proposta dos pesquisadores do Lume me serve para entender o ato interpretativo que, como profissional da cena, desenvolvi desde o início da minha carreira ${ }^{11}$. Por isso, devo acrescentar que, nessa perspectiva, fico só com o conceito de interpretação, dado que o de representação, como aparente contraponto, resulta-me insuficiente.

Jacques Derrida (2011), por exemplo, refere-se ao termo representação no sentido que Burnier dá ao de interpretação, associando-o com um tipo de ilustração sensível de um texto já escrito ${ }^{12}$. Por sua vez, o mesmo Ferracini (2013), em uma das suas últimas publicações, “Atuação como composição de afetos”, reconhece a insuficiência do termo:

11 Gostaria de esclarecer que, em nenhum momento, esta pesquisa pretende desvalorizar o trabalho do que chamo de ator-intérprete. De fato, o projeto artístico que aqui se descreve não entra em conflito com um fazer interpretativo, que continua me interessando, paralelo a essa busca autoral. Para apoiar minha "desculpa", cito de novo Ferracini (2013): “[a]o interpretar um texto, o ator realmente se coloca 'entre' a personagem e o espectador, como afirmava Burnier, uma vez que ele traduz, interpretando os signos literários em signos corpóreos e vocais para a construção de seu papel. Isto não impede ou diminui, em absoluto, a capacidade de também o espectador realizar sua própria interpretação, já que, se um signo remete a outro, o espectador traduzirá tais ações em outros signos imagéticos, sensoriais, emocionais. Ele sempre criará outros signos a partir de signos. O espectador é um criador diante do ator que interpreta, assim como o ator também é um criador quando cria, gera, interpreta signos a partir de um texto criado por outro. Sempre haverá interpretação, sempre haverá criação - somos todos interpretantes” (p. 56-57).

12 Por esse motivo, daqui para frente, uso a palavra representação como proposto por Derrida (2011). Falando sobre o teatro da crueldade de Artaud, o filósofo francês considera várias acepções do conceito. Além da já assinalada, pode ser entendido como: mimese da experiência humana (sua mais ingênua forma, o teatro deve ser o espaço primordial e privilegiado da destruição da imitação), repetição de um presente ausente à experiência dos espectadores e dos participantes da cena, exposição superficial para agradar a um grupo de curiosos e, finalmente, repetição como condição fundamental de todo signo. 
[...] agir (como é o caso do trabalho do ator) por representação, representar algo, é justamente colocar-se a serviço e falar a língua do senso comum, da doxa, designar os centros de referência que apontam para o já estabelecido. Em termos filosóficos é justamente o oposto do que Burnier almejava ao reconceituar o termo representação no território da cena. (p. 59-60, itálico no original)

No mesmo ensaio, Ferracini (2013) prefere usar o termo atuação ${ }^{13}$ :

[...] atuar se distancia em muito de representar uma personagem ou utilizar-se de alguma técnica de atuação. $\mathrm{O}$ verbo atuar aqui funciona como disparador de processos. Atuar $=$ disparar processos de compartilhamento de sensações, utilizando-se da materialidade corpórea como meio. (p. 71, itálico no original)

Longe de manter a discussão entre interpretação e representação proposta por Burnier para estabelecer os níveis de autonomia do ator em relação ao texto dramático, o conceito de ator-intérprete aqui se resgata precisamente nesse plano de dependência criativa. Minha experiência como intérprete (tradutor) das palavras e das intenções de outro, seja quem for (dramaturgo ou diretor), leva-me à busca de um maior estado de autonomia como única possibilidade próxima de alcançar um estágio autoral sem perder a condição de ator.

Voltando à ideia do ator como intérprete, parece uma constante dos historiadores do teatro considerar a arte do ator como sinônimo da arte da interpretação. Sobretudo, levando em conta que a maioria dessas histórias é escrita tendo como eixo a história da literatura

13 Nesse texto, Ferracini não só rejeita o termo representação para falar da arte do ator - como fez em publicações anteriores-, mas também o de interpretação. De fato, uma versão desse mesmo ensaio apareceu no livro Para uma história cultural do teatro, com o título "Nem interpretar, nem representar. Atuar" (Ferracini, 2010). É relevante que essa postura já tinha sido expressa por Tadeus Kantor, que pensava que o ator nem interpretava nem representava. Segundo Luiz Marfuz, o polonês apostava em uma prática de atuação, na qual o ator "não representa nenhum papel, não cria nenhuma personagem, nem a imita" (Kantor citado por Marfuz, 2013, p. 2). 
dramática. Salvo algumas exceções, como o caso de Ênio Carvalho (1989), que escreve uma história com a intenção de transferir esse eixo para a figura do ator, pouco se publica nessa perspectiva. Jean Jacques Roubine (2011) justifica esse fato dizendo que, até o final do século XIX, falava-se sobre os atores e escrevia-se muito sobre eles, mas raramente sobre a sua arte propriamente dita, dado que a literatura que se ocupava do ator quase sempre tinha um caráter anedótico. Além disso, pouca dessa literatura foi produzida pelos mesmos atores. Outros motivos seriam o efêmero da sua arte e o caráter coletivo dela, o que não acontece com outros artistas, como o escritor ou o pintor (Roubine, 2011).

Nessa perspectiva, Roubine (1998) crê que a relação com o texto é fundamental para entender as transformações que aconteceram com o ator durante muito tempo. "Existem mesmo boas razões para acreditar que a arte do ator só se renovou, de Molière a Talma, de Rachel a Sara Bernhardt, por meio de uma contínua interrogação sobre as tradições e as condições de interpretação dos textos" (p. 40). Interpretação será, para o pesquisador francês, a chave do entendimento da função do ator:

- “[...] o que compõe tem o dom da metamorfose e o tipo de trabalho sobre si mesmo ao qual ele se entrega garante uniformidade e durabilidade à sua interpretação" (Roubine, 2011, p. 90);

- "a interpretação se constitui de trocas entre o diretor e o ator" (Roubine, 2011, p. 102);

- “[a] arte do ator, como toda arte de interpretação, se baseia em premissas rigorosamente inversas” (Roubine, 2011, p. 107).

Além de colocar a questão da arte do ator como interpretação, Roubine também define o ator usando palavras como instrumento. Fechando o capítulo no qual fala das metamorfoses do ator, conclui que, nos últimos tempos, "[t]rata-se de fazer do ator um instrumento eficiente" (Roubine, 1998, p. 205).

Se Roubine encerra sua reflexão dessa maneira, Ênio Carvalho começa a dele dando uma definição de ator que se relaciona diretamente com o anterior. "Quando estivermos citando ator, estaremos 
referindo tanto o [sic] ator de teatro quanto o [sic] de cinema, de circo, de televisão, de radioteatro, etc., ou seja, aquele [sic] homem que é veículo de expressão de uma ação cênica para um determinado público" (1989, p. 12, itálico no original). Em palavras de Roubine (1998), o mesmo termo vale para Artaud (1999): “[...] o ator deve ser, e deve ser tão somente, o veículo de uma nova linguagem, cuja especificidade permitirá libertar a arte do espetáculo da tutela do texto e da significação discursiva” (p. 189). Carvalho (1989) também usará em alguns momentos a palavra transmissão para definir a arte do ator. "O ator é o transmissor da poesia, daí a ênfase para o seu aprimoramento técnico [...]" (p. 63).

Instrumento, transmissor ou veículo, afinal de contas, intermediário ${ }^{14}$; parece que os historiadores coincidem em entender a função do ator em geral como entendia Burnier, a do ator que interpreta. Isso se explica no grau de dependência que o ator tem em relação às outras figuras e funções do palco. Se a interpretação é produto da relação do ator com o texto dramatúrgico ou do ator com o diretor, como se apresentou nas palavras de Roubine, sair da interpretação demandaria um grau de autonomia que separasse o ator daquelas figuras. Os historiadores aqui citados parecem coincidir com essa afirmação. Posteriormente, farei referência a dois momentos da história do teatro que o confirmam. Por enquanto, também é importante demonstrar a existência dessa visão que associa o trabalho do ator ao de dramaturgos e diretores.

Segundo Roubine, a ideia do texto como elemento fundamental do acontecimento teatral e a consequente submissão do ator a ele ganha força nos primeiros trinta anos do século XX. Enquanto Gordon Craig e Antonin Artaud negavam seu lugar dominante, Jacques Copeau e Charles Dullin lhe rendiam adoração (Roubine, 1998). Copeau, por exemplo, para favorecer a fidelidade ao texto, exigia ao diretor um rígido controle sobre o ator, obrigando-o a se submeter completamente às exigências do texto (Roubine, 1998, p. 52). Nessa mesma

14 August Strinberg usaria a palavra médium. Segundo ele, o ator é um médium que "transmite o texto do poeta durante seu 'transe' cênico" (citado por Carvalho, 1989, p. 77-78). 
lógica, Jean Vilar, contemporâneo de Copeau e Dullin, chegou a dizer o seguinte: “[o] ator digno deste nome não se sobrepõe ao texto. Ele o serve. E servilmente" (Roubine, 2011, p. 91). Talvez Vilar, nessa perspectiva, concordasse com Denis Diderot, que escreveu no famoso Paradoxo sobre o comediante que atores e atrizes "servem para interpretar todos os [caracteres] porque não têm nenhum" (citado por Portich, 2008, p. 9). Será que interpretação e servidão estão aqui intimamente relacionadas?

Essa servidão do ator ao texto não é muito diferente da consagrada ao diretor. Embora Craig e Artaud rejeitassem a submissão ao texto, acreditavam na autoridade absoluta do encenador, especialmente sobre o ator, "cuja função instrumental devia ocultar qualquer investimento pessoal” (Roubine, 1998, p. 192). Ênio Carvalho, nesse sentido, assevera que Craig propôs a supermarionete ${ }^{15}$ para evitar a autonomia do ator, já que, segundo o teatrólogo inglês, ele deveria desaparecer em benefício das ideias (Carvalho, 1989).

O assunto da autonomia, então, passa a ser fundamental para entender a concepção do ator-intérprete, do ator-instrumento. Por isso, a ascensão do encenador como grande figura no final do século XIX torna conflitiva a relação diretor/ator.

Quando, nos fins do século XIX, a encenação se afirma por completo como arte, a inevitável consequência é um conflito de poderes. De um lado, o monstro sagrado, por sua própria presença, proclama a soberania do ator e o caráter exclusivo e direto de sua relação com o público, de outro, o diretor reivindica uma autoridade absoluta sobre tudo o que contribui para a representação.

15 Criticando os atores da sua época, Gordon Craig propôs a supermarionete. Ele considerava que o ator dependia muito das suas emoções e isso o tornava inconveniente para o teatro: "O ator deve sair e em seu lugar surgir a figura inanimada, a Supermarionete, podemos chamá-la assim, até que tenha conquistado para si um nome melhor" (Craig, 2012, s/p.). Depois de apresentar uma resenha histórica do papel das marionetes no mundo antigo e separá-las do conceito que agora temos de boneco como brinquedo, Craig defende a ideia de um teatro de volta à imagem, que pode prescindir da figura humana e que deixaria de tentar imitar a natureza. 
Não é à toa que no termo francês "régisseur" adotado por Craig, e mais tarde por Vilar, estava presente o verbo "régir" (comandar)... (Roubine, 2011, p. 103)

Daqui a pouco, voltaremos sobre a figura do monstro sagrado. Por enquanto, e sem desconhecer as qualidades do exercício da direção, é importante assinalar a tradicional dependência do ator da figura do diretor: "De Stanivlavski a Pitoëff, de Lee Strasberg a Peter Brook, desenvolveu-se e perpetuou-se esta teoria: o diretor deve agir como um revelador do ator, ele o ajuda a colocar para fora seu eu profundo, e a lhe dar forma" (Roubine, 2011, p. 105, itálico meu). Essa ideia popularizada até nossos dias vincula o trabalho do ator ao do diretor.

Georges Pitoëff (citado por Roubine, 2011), validando a concepção anterior, afirmava: "[u]ma vez que eu tenha conseguido passar para dentro do ator a chama que está em mim, eu o deixo livre" (p. 105). Roubine critica essa suposta liberdade questionando a ideia de ser livre quando se tem o outro dentro de si, mas acaba rendido à ideia ao concluir que o ator se faz na renúncia à liberdade.

Afinal, no teatro, talvez seja necessário e suficiente que o ator tenha a ilusão da liberdade. E poderia ser diferente? A escolha primordial de todo ator não é precisamente se alienar, mergulhando no papel? A arte do ator talvez comece por esta renúncia. (Roubine, 2011, p. 105)

A proposta desta pesquisa começa precisamente no ponto contrário. $\mathrm{Na}$ lógica do pesquisador francês, a arte do ator continua delimitada pela sombra do encenador. Na renúncia à alienação —entendendo esta última como renúncia à autonomia-, este trabalho encontra sua motivação. De igual forma, esta pesquisa deambula através de um panorama que espera que o ator em si, sem intermediação do diretor, possa colocar para fora seu eu profundo.

No entanto, nem sempre existiu essa relação de dependência do ator com o texto ou com uma figura externa que o governasse. A história do teatro registra um momento no qual o ator assumiu seu ofício de maneira autônoma, sem ficar preso ao império do texto ou do encenador. Estamos falando da commedia dell'arte. Os historiadores 
coincidem em afirmar que aquele momento passou à história como o período do "reinado" do ator. "Vamos, agora, observar os intérpretes profissionais, os comediantes mais populares, como os da commedia dell'arte, onde o ator dominava soberanamente, ao ponto de ela ser considerada o primeiro grande laboratório do teatro moderno" (Carvalho, 1989 , p. 41). Para o pesquisador, trata-se, pois, da "primeira grande escola de ator na evolução na história do teatro" (Carvalho, 1989, p. 28).

Roubine também segue a mesma linha. O teórico é enfático ao afirmar que se deve à commedia dell'arte verdadeiras criações de ator. Sustenta sua asseveração dizendo que "Pantaleão e Arlequim, por exemplo, nada devem, na origem, ao gênio criador de escritores" (Roubine, 1998, p. 187). Além disso, uma comparação feita por ele a respeito dos níveis de autonomia criativa entre os atores da commedia dell'arte e os de uma cena mais contemporânea justifica a alusão que se propõe nesta parte da pesquisa.

Um dos traços mais notáveis desse teatro é talvez o de que o ator, na tradição ocidental, jamais dispôs de uma tão grande liberdade, quer dizer, de uma tão grande responsabilidade criadora. Sua representação se baseia, sabemos, na improvisação, coisa que as dramaturgias de texto excluem, ou ao menos limitam sensivelmente. Limitação esta que, hoje em dia, provém de dois tipos de pressão: 1) o ator deve representar todo o texto e nada além do texto; 2) a encenação integra o trabalho pessoal do ator em um sistema que, ao mesmo tempo, o ultrapassa e se impõe a ele de maneira normativa e diretiva. Ao contrário, os roteiros da commedia dell'arte fazem do ator a fonte principal (senão única) de seu texto e de sua representação. (Roubine, 2011, p. 81-82)

Não é produto do acaso, então, que Ferracini aluda à commedia dell'arte como exemplo de atores não interpretativos.

É importante observar aqui, não a Commedia Dell'Arte em si, como a descrição pormenorizada de cada máscara e tipo, mas o que ela suscita para a arte de ator no sentido de sua autonomia artística 
em cena. Aqui, o texto perde sua majestade. Acaba qualquer tipo de interpretação [...] (Ferracini, 2001, p. 59, itálico no original)

A commedia dell'arte é reconhecida, nesse sentido, como um momento de "soberania" e "majestade" do ator —Ferracini (2001) o chama de "senhor do espetáculo" (p. 70)—. A experiência teatral toda era baseada no ator e, em lugar de texto dramatúrgico, como o entendemos agora, o que existia era uma espécie de roteiro de situações (os canovacci).

Os atores da commedia dell'Arte tinham outra relação com a escrita dramatúrgica. No prólogo de Finto Marido, comédia escrita por Flamínio Escala em 1968, o comediante dell'arte anota: “a experiência faz a arte, porque muitos atos reiterados fazem a regra e, se os preceitos se extraem desta, então dessas ações se tira a verdadeira norma, portanto o comediante pode ditar as regras aos que compõem comédias, não estes, àqueles" (citado por Portich, 2008, p. 54). Essa falta de apego dos atores a uma literatura dramática que lhes antecedesse é o argumento principal que dá Ferracini para falar da técnica deles como não interpretativa. No entanto, o assunto não fica reduzido a isso. De fato, a improvisação com recurso próprio da arte do ator também é reconhecida como responsável da audácia e da independência desses atores.

Em algum momento de sua argumentação, Ferracini (2001) propõe substituir a palavra improvisação por "liberdade de expressão" (p. 73), a qual se encontra representada no desapego a formas predefinidas e estáticas, mesmo que o ator recorra ao arsenal de matérias-primas que guarda na sua memória corporal, o que era constante no exercício dos atores dell'arte (Roubine, 2011) ${ }^{16}$. Essa liberdade de expressão também

16 De outro ponto de vista, a pesquisadora Cleise Furtado Mendes não parece concordar completamente com essa ideia de desapego e autonomia no caso dos atores dell'arte. Partindo da polêmica que começou com o interesse do comediógrafo Carlo Goldoni por escrever propriamente "textos" que substituíssem os roteiros usados pelos atores na commedia dell'arte, a pesquisadora brasileira coloca a proposta do dramaturgo como uma tentativa de transformar a fixidez e a abstração dos tipos tradicionais nos quais se especializavam os atores da época (Mendes, 2008). De alguma maneira, Furtado traz à tona um assunto pouco explorado pelos historiadores, que é a dependência 
se manifestou, segundo o registra a pesquisadora Ana Portich, no fato de serem os comediantes dell'arte os primeiros a escrever especificamente sobre o ator (2008). Relevante coincidência ${ }^{17}$.

Passando a outro assunto, como prometido, farei referência a outro período de "soberania" do ator. Talvez não observado tão positivamente pelos historiadores como acontece com a commedia dell'arte, o momento dos chamados "monstros sagrados” servirá para fechar esta parte.

Quando falo de monstros sagrados, faço questão de lembrar algumas figuras míticas para a história do teatro como Sarah Bernhardt (1844-1923), Henry Irving (1838-1905) e Eleonora Duse (1858-1924), entre outros. Roubine fala deles usando a expressão ator-mago. Segundo ele, "reinavam" no palco no começo do século XX e as impressões que causavam suas interpretações pareciam produto de um sopro divino, dado que "esses atores imprimiam ao desempenho dos seus personagens uma força inteiramente excepcional” (Roubine, 1998, p. 175).

Em primeiro lugar, o monstro sagrado aparece — sobretudo no palco - como um ser completamente excepcional. Monstruoso tanto no sentido do habitual - intérprete que desafia todas as normas, transgride $[s i c]$ todas as regras como no sentido etimológico de prodígio (monstrum). E fácil de perceber que essa singularidade de monstro sagrado acaba orientando e norteando todo o

dos atores há mais de dois séculos de tradição de teatro cômico italiano, o que inclui tipos e situações fixas que eram "exigidas” pelo gosto da época. Nessa ordem de ideias, os atores dell'arte não teriam a dependência do texto dramatúrgico que apareceu depois na tradição ocidental, mas estariam presos a outro tipo de exigências.

17 Em termos do desenvolvimento prático desta pesquisa, deu-se outra coincidência entre os procedimentos usados pelos atores dell'arte e a busca de um tipo de criação autônoma do ator. Embora o uso de roteiros não tenha sido inspirado pela commedia dell'arte como procedimento da cena, o processo criativo que se descreve neste livro acabou chegando até eles como resposta a uma lógica que desistiu da necessidade de um texto dramatúrgico anterior para a construção da ficção e como meio para aparição da palavra no palco. Isso se explica mais detalhadamente no terceiro capítulo. 
espetáculo. Este não é mais elaborado tendo como referência uma obra, por mais prestigiosa que seja, mas como uma concha destinada a conter a singularidade em questão. [...] Ocorria que esse tipo de intérprete transmitia a sensação de estar além de qualquer técnica (por mais que uma técnica vocal e gestual - às vezes, ao que parece, bastante simples - fosse posta em ação), num domínio de pura autenticidade, de uma mágica simbiose da personalidade do ator com seu personagem. (Roubine, 1998, p. 174-175)

Eis a chave do meu interesse por essas figuras. $\mathrm{Na}$ exploração da singularidade aparecem esses gênios criativos. "A arte do monstro sagrado exigia que ele fosse o seu próprio diretor, de modo que não viesse limitar ou perturbar uma metamorfose na qual ele se engajava por inteiro" (Roubine, 1998, p. 176, itálico no original). Parece aqui uma nova conexão com esta pesquisa: o fato de serem atores que trabalhavam sem diretor. Roubine chama a atenção, no entanto, sobre um assunto que obscurece a visão que desses seres se tem: trata-se de uma arte narcisista? A seguir, a resposta de Roubine (1998).

Sem dúvida. Mas parece preferível, no caso, abster-se de emitir um julgamento até certo ponto marcado pelo puritanismo, e reconhecer que o narcisismo e o exibicionismo podiam, afinal de contas, constituir-se em trampolins de um tipo de representação manifestamente não desprovido de grandeza nem beleza. (p. 176)

Essa afirmação de Roubine chamou minha atenção e acabou sendo objeto de reflexão no meio dos ensaios do meu espetáculo unipessoal, tendo em vista que constantemente me questionam o fato de trabalhar sem diretor. O processo criativo da peça está acompanhado pela escrita de um blog que publica avanços e reflexões desse exercício. Nesse blog (González, 2013b), adverti sobre esses personagens pela mesma preocupação que se faz evidente na resposta de Roubine, dado que essa busca de singularidade a partir de um ator que pretende tomar o controle da encenação costuma se confundir com autossuficiência e altas doses de idolatria. Se, como diz Ferracini, a potência do unipessoal se encontra na possibilidade de coletivizar uma singularidade, por que não levar isso até as últimas 
consequências? Certamente, a singularidade de Sarah Bernhardt lhe deu um lugar excepcional na história do teatro ocidental. Talvez esse debate seja só um desejo de validez histórica.

Claro que a relação do monstro sagrado com o conceito de encenação como é entendido agora resulta conflitivo — de fato, Roubine (1998) afirma que essa questão colocava ao monstro sagrado na contramão da evolução do teatro-, mas aqueles atores trabalhavam com sua singularidade e era principalmente ela a que atraía o público. Tratava-se de uma época na qual o vedetismo definia a figura central da cena.

Contudo, não estamos em uma época que dá essa centralidade do acontecer cênico ao encenador? Os historiadores assim o confirmam e também as condições de produção que dominam o mundo do espetáculo teatral atual. Voltando a Burnier, na conclusão do seu texto, diz:
[...] quem é o artista do palco, o diretor ou o ator? Esta guerra, hoje, parece-me mais pelo poder do que pela arte. Na estrutura do teatro contemporâneo, os atores dependem, infelizmente, dos di- retores para terem emprego, e, portanto, é ele quem manda. Mas me parece que nós temos aqui um típico caso de assalto. $\mathrm{O}$ diretor tomou de assalto o teatro, e ponto final. $(2009$, p. 248)

Não é interesse desta pesquisa discutir essa disputa, sobretudo, porque acredito que a obra de arte tem valor por si mesma e para o espectador talvez nem seja preciso fazer essas distinções. O que me interessa é validar esse desejo de autonomia criativa e, para isso, é importante responder parcial e especificamente à pergunta de Burnier no panorama criativo da minha proposta, sem desconsiderar os exercícios estéticos que saem da opção contrária, tão válidos enquanto este. Na seção seguinte, no entanto, voltaremos ao tema.

\section{A questão da autoria no teatro}

Sendo o eixo desta pesquisa a tentativa de ultrapassar a categoria de ator-intérprete com o interesse de alcançar a de ator-autor a partir das potencialidades do espetáculo unipessoal, é fundamental entender, em 
primeira instância, o que se entende por autor no teatro. No entanto, começarei a indagação problematizando o termo à luz de Michel Foucault, que deu uma conferência que partia precisamente da questão: o que é um autor ${ }^{31}$. Dela, extraio a acepção que me interessa para os objetivos da pesquisa.

A argumentação de Foucault (2001 [1969]) parte da ideia da morte do autor, declaração que foi proferida por Roland Barthes em 1968, um ano antes da aparição da conferência de Foucault. Para Barthes, essa ideia dá conta de uma saturação em relação à sobrevalorização do indivíduo e ao reconhecimento de diversas tradições que ultrapassam os discursos e as obras. Nesse sentido, o filósofo fala do autor como uma invenção.

O autor é uma personagem moderna, produzida sem dúvida pela nossa sociedade, na medida em que, ao terminar a Idade Média, com o empirismo inglês, o racionalismo francês e a fé pessoal na Reforma, ela descobriu o prestígio pessoal do indivíduo, ou como se diz mais nobremente, da "pessoa humana". (Barthes, 2004, p. 1)

Foucault reconhece o valor das palavras de Barthes e as implicações delas no mundo das ideias. Sua conferência, efetivamente, parte dessa afirmação, porém, como ele mesmo esclarece, sua contribuição não se trata de afirmar essa morte, mas sim de ver, a partir do tema, de que maneira e sob quais regras se forma o conceito de autor e como ele funciona. Por isso, no seu texto, aprofunda mais a questão da função autor do que a definição do conceito autor propriamente dito.

18 Tomar como ponto de partida a conferência de Foucault para tentar determinar a possibilidade de pensar a categoria de ator-autor não é uma proposta exclusiva desta pesquisa. A pesquisadora Fernanda Coutinho Bond, da Universidade Federal do Rio de Janeiro, em uma comunicação apresentada no VI Congresso de Pesquisa e Pós-graduação em Artes Cênicas de 2010, insinua essa possibilidade. Embora só nomeie a questão, vale a pena ressaltar o interesse que suscita o texto foucaultiano no mundo do teatro. A diferença com o proposto aqui é a abordagem a partir de um trabalho mais próximo à performance (Coutinho-Bond, 2010). 
Outro esclarecimento importante se refere a que o filósofo se concentra em falar dessa função em relação à produção textual escrita, mas faz explícita sua convicção de que, ainda precisando de um estudo mais aprofundado, a função autor na pintura, na música, nas técnicas etc. (aqui, dou-me a liberdade de incluir o teatro) pode ter muito em comum com sua argumentação. Essa limitação do tema, no entanto, parece-me muito pertinente no sentido de que, como se reflete mais adiante, o grande autor do teatro, pelos menos em termos históricos, é o escritor.

Foucault começa sua reflexão determinando os locais onde a função autor é exercida: no nome (na impossibilidade de tratá-lo como uma discrição definida ou como nome próprio comum); na apropriação (ele não é exatamente proprietário, nem responsável, nem produtor, nem inventor de seus textos); na atribuição (o autor é, sem dúvida, a quem se atribui o que foi dito ou escrito) e na posição (espaço físico ou virtual que ocupa no livro, no discurso ou no campo de conhecimento) (Foucault, 2001).

O filósofo (2001) afirma que a figura do autor constitui o momento crucial da individualização na história das ideias, dos conhecimentos, das literaturas e na história da filosofia e das ciências. Essa individualização se relaciona com assuntos que definiriam a ideia mais romântica de autor como gênio, como portador de uma verdade que lhe pertence. É por isso que, quando se fala de autoria em termos mais pós-modernos, ela é entendida como produto de diversas experiências que se entrelaçam mais do que de um tipo de iluminação individual. Sobre esse assunto, o pesquisador colombiano Jaime Alejandro Rodríguez (2004) assinala o seguinte: "[a] figura do autor, cuja imaginação criadora se tinha como fonte da literatura, começa a ser assumida mais como a de um 'assembler' de diversos fragmentos da cultura e como um montador de colagens ou textos” (p. 103, tradução minha).

Como pressuposto teórico para a criação do espetáculo unipessoal que esta pesquisa procura, a definição de Rodríguez é muito mais próxima e estimuladora do processo criativo do que a postura tradicional que tanto Foucault quanto Barthes problematizam. Sobre esse autor -Rodríguez-, voltarei a falar no capítulo final, que trata dos procedimentos autorais que esse tipo de perspectiva oferece. 
De volta ao tema da autoria entendida como individualização, essa postura poderia explicar as razões pelas quais, no campo do teatro, sua história acaba sendo escrita sob o eixo da dramaturgia, em cujo interior a definição de autoria é muito mais clara. Continuando com sua argumentação, Foucault (2001) se concentra em estudar quatro características da função autor:

[...] a função autor está ligada ao sistema jurídico e institucional que contém, determina, articula o universo dos discursos; ela nasce e se exerce uniformemente e da mesma maneira sobre os discursos, em todas as épocas e em todas as formas de civilização; ela não é definida pela atribuição espontânea de um discurso ao seu produtor, mas por uma série de operações específicas e complexas; ela não remete pura e simplesmente a um indivíduo real, ela pode dar lugar simultaneamente a vários egos, a várias posições-sujeito que classes diferentes de indivíduos podem vir a ocupar. (p. 284)

Essas características permitem entender que aquilo que conhecemos como autoria tem a ver com uma série de convenções que, em primeiro lugar, atribuem “donos” às obras para validar discursos, o que funciona de diferentes maneiras em cada época e o que sustém seu fundamento nos sistemas de propriedade intelectual. Foucault (2001) afirma, por exemplo, que, no caso da literatura, o anonimato só é suportável se aceito na qualidade de enigma. No entanto, o filósofo afirma que aquilo que, no indivíduo, é designado como autor é a soma de traços que estabelecem continuidades e exclusões, que nem sempre são tão fáceis de identificar.

O que fica claro com a proposta de Foucault é a questão da atribuição. Como consequência de convenções que marcam cada época, diferentes nomes têm recebido a categoria de autores e, em muitos casos, nem se tem certeza da existência desses seres (Hipócrates e Homero, por exemplo, citados por Foucault), sejam eles indivíduos, representantes de alguma coletividade, sejam simples abstrações. Por enquanto, tomarei o sentido de atribuição da função autor para analisar quem a tem recebido na prática teatral. Em capítulos posteriores, 
quando este livro se ocupar de constatar a possibilidade de falar de um ator-autor, produto da experimentação criativa que aqui se propõe, voltarei a Foucault.

Seguindo essa perspectiva, então, quem é considerado o autor do acontecimento teatral? À primeira vista, a resposta, para o mais democrático dos olhares, pode se achar na condição coletiva da arte teatral. Seria possível dizer que cada um dos participantes da montagem teatral contribui com uma porção de autoria. Nas práticas mais politicamente corretas, cada um deles recebe os créditos pelo trabalho feito: figurinistas, cenógrafos, sonoplastas, atores, dramaturgos e diretores, entre outros. Reconhecidas como criadoras, essas figuras conseguem equiparar suas intervenções como contribuições para a realização do acontecimento cênico. No entanto, partindo precisamente da questão da atribuição, duas delas gozam de uma categoria superior à das outras. Trata-se do dramaturgo e do diretor ou encenador.

Seguindo uma tradição ocidental que especializou as profissões teatrais e hierarquizou-as, escritores e encenadores costumam ocupar a posição mais alta dessa estrutura. Para corroborá-lo, volto à figura de Jean-Jacques Roubine. No já citado livro A linguagem da encenação teatral (1998), ele é claro ao afirmar que o teatro ocidental não escapou dessa hierarquização de competências e que habitualmente colocou no topo o dramaturgo (o teórico francês se referirá a este sempre como autor), não sem antes reconhecer a ascensão do encenador no século XX.

Nesse panorama, é evidente que a tradição ocidental deu o lugar da autoria do espetáculo teatral ao dramaturgo. Isso porque, em uma prática que considera o texto elemento dominante da cena, ele se constitui ponto de partida obrigatório para a construção do espetáculo. Considerando o terceiro local onde se exerce a função autor, segundo Foucault, é evidente que, no teatro, a nenhum outro participante se atribui o dito ou o escrito como ao dramaturgo. As razões para atribuir a propriedade dos conteúdos do espetáculo teatral ao dramaturgo têm a ver com o costume de dar à escrita um estatuto originário (Foucault, 1969).

Eu mesmo, por exemplo, quando escrevo meu currículo e faço uma lista das peças nas quais trabalhei como ator ou diretor, coloco um "de" depois do título do espetáculo, seguido do nome do dramaturgo. Essa 
prática, tão comum na cotidianidade do fazer profissional teatral hoje, o que também pode ser constatado em cartazes e programas, ainda se tratando de versões livres, mantém essa hierarquia que dá prioridade à concepção e às intenções do escritor, como se a criação "primeira" lhe correspondesse e lhe fosse exclusiva. Assim, falar do dramaturgo como autor é quase uma obviedade.

Voltando ao dicionário de Patrice Pavis, no verbete autor dramático, o teórico francês assinala que o termo é usado como equivalência de dramaturgo e que o autor dramático é o primeiro elo da cadeia de produção da encenação (Pavis, 2008). Embora essa ideia de colocar o dramaturgo como primeiro elo da encenação seja relativa porque depende do tipo de produção da qual faz parte, a proposta de Pavis confirma a generalização hierárquica que deixa o escritor no lugar mais alto. O verbete dramaturgo, por sua vez, sugere uma etimologia que vincula a palavra ao grego dramaturgos (autor dramático) (Pavis, 2008).

Nessa perspectiva, pode-se afirmar que o autor do teatro seria aquele que provê os materiais verbais à encenação, o dono da pala$v \mathrm{ra}^{19}$. Eis o lugar onde começa a grande discussão sobre a questão da autoria no teatro, herdada da tradição literária, na qual a figura do autor se torna menos nebulosa.

Essa dependência do texto literário é uma das considerações de Antonin Artaud (1999) quando anuncia a necessidade de libertar o teatro da ditadura da palavra. O teatro ocidental idolatrou por muito tempo a figura do dramaturgo e construiu ao seu redor as bases da sua

19 Quando se fala em materiais para o caso do trabalho do ator, sempre se faz referência às ações físicas. Se o material principal do dramaturgo é a palavra, o do ator é a ação. Isso leva à popularização da expressão dramaturgia do ator, usada frequentemente por Eugenio Barba. Por dramaturgia do ator, Barba (2010) entende tanto a "[...] contribuição criativa no crescimento de um espetáculo quanto [...] sua capacidade de enraizar o que contava numa estrutura de ações orgânicas” (p. 57). Assim, a dramaturgia do ator é um termo importante para entender as "contribuições" que ele faz na criação da encenação. As partituras de ações que ele produz determinariam aqueles espaços de criação autônoma: "A dramaturgia do ator era a medida de sua autonomia como indivíduo e como artista” (Barba, 2010, p. 58). 
estrutura. Assim, o dramaturgo era considerado o "verdadeiro criador" do teatro. Segundo Roubine (1998), o escritor na tradição europeia, como criador do texto, "era tido como a instância ao mesmo tempo primordial e final de toda a responsabilidade" (p. 48-49). Essa atitude faz com que as figuras de encenador e de ator, por exemplo, sejam relegadas ao papel de simples intérpretes das intenções do dramaturgo. Jean Vilar, citado por Roubine (1998), dizia: “[o] criador, no teatro, é o autor - na medida em que contribui com o essencial” (p. 56). O “essencial”, então, seria a palavra. Isso será confirmado pelo mesmo Vilar (citado por Roubine, 1998) quando concede ao ator "uma arte de criação autêntica": a mímica (p. 56) ${ }^{20}$.

Nesse sentido, Jacques Derrida, no ensaio acima citado sobre Artaud e seu teatro da crueldade, critica o teatro dominado pela palavra de um autor ausente e distante —ao qual dá o nome de "palco teológico"-, que pretende ser representado por diretores e atores, os quais não deixam de ser simples intérpretes subjugados às supostas intenções daquele autor. "Escravos interpretando, executando fielmente os desígnios providenciais do 'senhor'” (Derrida, 2011, p. 343). O filósofo francês acredita que a liberdade instauradora e criadora da encenação pode ser restituída se libertada do texto e do deus-autor ${ }^{21}$.

A ditadura do escritor no teatro ocidental traz consequências de naturezas diversas sobre o fazer teatral e sobre a definição dos papéis criativos. Isso se reflete em uma história do teatro que, até o começo do século XIX, considerou o trabalho de encenadores e de atores similar ao do artesão, o que muda quando se fala do século XX como o século do encenador.

20 Talvez isso explique por que, no chamado de teatro físico - eu prefiro a expressão teatro de corpo manifesto proposta por Lúcia Romano (2008)—, as qualidades autorais do ator parecem ser mais claras.

21 Derrida esclarece que isso não quer dizer que a palavra deva ser expulsa do teatro. Todo o contrário, é um convite a lhe dar o lugar que merece, devolver sua intensidade, sua sonoridade, liberá-la do papel dominador que a tradição ocidental deu para ela. Fazer da palavra um dos elementos do teatro é reconstituir sua função como escritura, a qual não se assemelhará ao modelo da representação clássica (Derrida, 2011). 
O surgimento do encenador na segunda metade do século XIX ${ }^{22}$ determinou uma série de transformações que fizeram com que a figura do dramaturgo fosse deslocada do seu papel central. A encenação, então, ganhou terreno na apropriação de um protagonismo criativo e autoral. Precisamente, nesse sentido, Artaud usa o conceito de encenação como motivador de um novo teatro que se libera daquela ditadura do texto. Mesmo que não se detenha na figura do encenador, como fizeram outros visionários de seu tempo, sua valoração da encenação abre as portas ao tempo desses criadores. No primeiro manifesto de seu teatro da crueldade, anuncia:

[é] em torno da encenação, considerada não como o simples grau de refração de um texto sobre a cena, mas como o ponto de partida de toda criação teatral, que será constituída a linguagem-tipo do teatro. E é na utilização e no manejo dessa linguagem que se dissolverá a velha dualidade entre autor e diretor, substituídos por uma espécie de Criador único a quem caberá a dupla responsabilidade pelo espetáculo e pela ação. (Artaud, 1999, p. 106-105)

O momento do diretor como autor do acontecimento teatral chega quando aparece um grupo de encenadores que renuncia a ideia de serem meros ilustradores do texto dramatúrgico. Gordon Craig será um dos primeiros a anunciar a possibilidade do encenador como autor. Em 1905, Craig estava propondo a supressão do autor dramático como elemento central da cena e convidando ao uso da palavra como um dos vários elementos do acontecer cênico e não como assunto predominante.

No primeiro diálogo do texto Da arte do teatro, Craig provê as bases daquele pensamento que assinala o encenador como a grande figura do teatro, partindo de desconsiderar o texto como elemento

22 “Apesar dos precedentes históricos ligados ao próprio exercício da cena, seria o caso de reservar o termo encenação, e mais ainda o de encenador, para as experiências cênicas a partir dos anos de 1880, visto que a era dos encenadores não começou antes da crítica radical ao teatro feita por Zola ou Antoine, da mesma maneira que não começou 'nem antes' da contraproposta do simbolismo" (Pavis, 2010, p. 2, itálico no original). 
fundador. No começo do diálogo entre "o amador de teatro" e "o encenador", Craig é enfático ao afirmar que a peça é uma obra literária e, assim, não pode ser o essencial do teatro. $\mathrm{O}$ amador de teatro diz: "[s]empre pensara que nascera do discurso e que o Poeta presidira ao seu destino" (Craig, 1963, p. 159). A isso, o encenador responde com uma ampla reflexão sobre o papel do escritor no teatro, ponderação que conclui com as seguintes palavras: "[e]ntre os escritores, só o dramaturgo pode, pelo seu nascimento, fazer valer um direito ao teatro e, mesmo assim, esse direito é muito fraco" (Craig, 1963, p. 162).

Depois disso, Craig assinala o fato de que o público vai ao teatro para ver e não para ouvir. Por isso, considera, por exemplo, que as peças de Shakespeare são tão completas e tão vastas no ato da leitura que, no da representação no palco, só podem perder (Craig, 1963). É, portanto, um grande erro, a partir do ponto de vista de Gordon Craig, manter o dramaturgo como a figura principal do espetáculo. Linhas depois, Craig anuncia "a chegada do artista" ao mundo do teatro, o qual mudará tudo. Esse artista é o encenador. "Nesse dia já não teremos necessidade do dramaturgo. A nossa arte será independente" (Craig, 1963, p. 167). Depois, afirmará que o renascimento da arte do teatro estará estreitamente ligado ao encenador (Craig, 1963, p. 167).

Em outro texto importante de Craig, "Os artistas do teatro do futuro", o autor retoma a figura do encenador ${ }^{23}$ para dizer que a natureza das suas funções faz dele a personagem principal do mundo do teatro ${ }^{24}$ (Craig, 1963). Nesse ponto, e lembrando que Roubine

23 Na edição citada (Craig, 1963), o termo será traduzido como ensaiador neste primeiro capítulo. Roubine (1998, p. 59) esclarece que o termo original usado por Craig é régisseur, o qual, na terminologia dele, é sinônimo de diretor ou encenador.

24 Craig concebe a existência de encenador ideal que reuniria todos os talentos em uma pessoa: “[...] um homem que teria sido ator, depois desenhador de cenários e figurinos; que conheceria as técnicas da iluminação e da dança o sentido dos ritmos; que seria capaz de dirigir os ensaios dos atores; capaz, numa palavra, de acabar pela sua invenção a obra que, do ponto de vista cênico, o poeta deixara incompleta" (Craig, 1963, p. 218). Nesta pesquisa, procura-se um ator que, como aquele encenador ideal, possa transitar pelo exercício criativo dessas diferentes funções do espetáculo teatral. 
mostra como, naqueles primeiros trinta anos do século XX, Craig e Artaud negaram o papel predominante do texto na realização do espetáculo teatral, autores como Jacques Copeau se mostravam completamente obedientes a ele (Roubine, 1998) e radicais na sua concepção do valor do texto teatral. Assim, afirmava: “[p]enso que para uma obra adequadamente concebida para o palco existe uma encenação necessária, e uma só: a que está escrita no texto do autor" (Copeau citado por Roubine, 1998, p. 53). Portanto, como se mencionou quando falamos do ator-intérprete, se a obrigação do encenador era, segundo Copeau, impor ao intérprete se submeter às exigências do texto e ele, por sua vez, teria que se subordinar às imposições do dramaturgo, quais possibilidades criativas ou autorais haveria para diretores e atores nessa perspectiva?

Do ponto de vista contrário, o encenador poderia considerar o dramaturgo como um indivíduo estranho ao teatro e o texto teatral como um elemento técnico a mais da criação cênica. O século XX chega com essa premissa e permite a aparição daquela grande figura autoral: o encenador. Liberado de seu papel de intérprete das intenções do dramaturgo, o encenador representa aquela autonomia que especifica a qualidade do acontecer teatral e liberta a prática da representação da peça literária. Roubine usa a figura de Gaston Baty para apresentar essa questão.

$\mathrm{Na}$ França, Gaston Baty reagiu por sua vez contra a submissão da encenação ao texto, e retomou, ou reencontrou as ideias de Craig sobre a supremacia do encenador: a finalidade do teatro é o espetáculo. Este só adquire a perfeição e a homogeneidade que configuram uma obra de arte quando o encenador está na plenitude de seus direitos como autor, como inventor. (Roubine, 1998, p. 62)

Chegará então o tempo de Vsévolod Meyerhold, Bertolt Brecht, Eugenio Barba, Jerzy Grotowski e Peter Brook, entre muitos outros, encenadores que se relacionam com o texto de outra maneira, deslocando o dramaturgo do lugar da autoria e assinando com seus próprios nomes os espetáculos de suas companhias. 
Parece que é nesse afastamento da fidelidade devida ao texto literário que o encenador adquire, na virada do século XIX-XX, seu lugar como autor do espetáculo. Walter Lima Torres, em um artigo que tenta apresentar três possibilidades de entender a direção teatral por meio de uma breve contextualização histórica, parte dessa relação para determinar aquela tipologia. Sobre o assunto que nos interessa, diz:

[o] primado da cena sobre a dramaturgia não deixa de ser uma espécie de revanche natural que responde aos projetos de um $\mathrm{E}$. G. Craig, Antonin Artaud, Adolphe Appia e tantos outros que idealizaram, há cem anos atrás, uma cena alforriada da literatura dramática. À cena desses criadores verifica-se uma radicalização da sua expressão por conta de uma "assinatura" bastante forte e definida em termos poéticos. A condição de trabalho a qual o encenador parece alcançar, com seus procedimentos e resultados, pode ser comparada àquela quando o cineasta conquistou a posição de autor, ou realizador de seu próprio filme. (Lima, 2007, p. 119)

Nesse mesmo artigo, afirma-se também que a produção de subjetividade que o diretor teatral projeta sobre o texto do dramaturgo problematiza a questão da autoria da cena (Lima, 2007), o que mostra a importância de seu surgimento como figura que muda a tradição teatral ocidental. Sobre esse assunto, o Dicionário do teatro brasileiro, no verbete dedicado ao tema do encenador, assinala a seguinte questão:

[...] a prática teatral do encenador não deixou de se questionar permanentemente acerca de duas tendências que alimentam o debate teatral até hoje: ser o fiel porta-voz do autor teatral, ou reivindicar para si a autoria do espetáculo?

[...] Coloca-se, na verdade, a questão autoral do encenador e seu esforço por uma cena autônoma, uma assinatura que identifica a obra estética, a encenação. (Guinsburg, Faria e Alves, 2006, p. 124) 
Fica clara, então, a atribuição do caráter autoral recebida pelo encenador. Embora continue, em alguns espaços, a polêmica entre quem é o autor do teatro —-dramaturgo ou diretor-, ambas as figuras recebem o tratamento de autores. Alguns acadêmicos, mais generosos, vão reconhecer a dupla autoria desses criadores. Isso faz com que essa relação, ao contrário, possa ser harmônica e não necessariamente distante. A famosa frase "não tem melhor autor que o autor morto" não se aplica nesses exercícios mais colaborativos. Na continuação, um exemplo de uma pesquisadora mexicana que concede a autoria "compartilhada" como possibilidade de parceria criativa:

[...] pode-se assumir que se existe um autor do texto dramático o dramaturgo que escreve a peça literária - existe, então, o autor da representação, que é o diretor que cria a encenação. Para Edward Wright "no momento em que a peça escrita se transforma em uma peça teatral, entra em um meio novo e, portanto, o diretor é tão criador quanto o dramaturgo" ${ }^{25}$. (Sánchez-Aguilar, 2011, tradução minha, itálico no original)

$\mathrm{E} \mathrm{o}$ ator? Tem algum espaço nessa paisagem para assumir seu lugar autoral? Na hierarquização das profissões teatrais acima nomeadas, a interpretação tem sido sua função principal, seja da voz do dramaturgo, seja das ideias do encenador. No início, só como porta-voz da mensagem do "deus-autor", o ator já percorreu um longo caminho que acaba no reconhecimento de suas qualidades criativas, concedendo-lhe atribuições que podem se aproximar à categoria de autor, sobretudo no interior da estrutura de grupo.

No entanto, a figura do ator ainda não parece encontrar o estágio de autor que faz uso de sua autonomia criativa, o que fizeram os encenadores ao se libertarem das imposições dos escritores. Sua dependência do governo do encenador continua sendo muito apreciada,

25 O texto citado por Sánchez-Aguilar corresponde a: Wright, A. E. (1982). Para comprender el teatro actual. México: Fondo de Cultura Económica. 
a tal ponto que o trabalho de atores autônomos que se libertam da tutela de um diretor ainda é motivo de desconfiança.

Se aceitarmos que o encenador alcançou seu status de autor no momento em que conseguiu independência do dramaturgo e no qual renunciou a uma função exclusivamente interpretativa do texto dramatúrgico, esta pesquisa parte da hipótese de que uma ação homóloga para o caso da relação encenador-ator poderia dar esse espaço para o ator.

Mas deixemos, por enquanto, o assunto da autonomia e reconheçamos que, em processos criativos nos quais a figura do encenador deixa de ser entendida como autoridade única, as possibilidades autorais do ator, pelo menos em potência, começam a ser vislumbradas.

\section{À busca de um ator-autor}

A criação coletiva aparece como um terreno no qual o ator se aproxima mais da possibilidade de atingir uma categoria autoral. Sobre isso, Roubine diz que, após Grotowski, o ator e a coletividade em que ele se insere participam mais ativamente da criação textual: "[d]aí em diante, é o conjunto de todos os que representam o texto que se constitui no seu autor coletivo" (Roubine, 1998, p. 73). Mesmo que essa afirmação continue sendo parte de uma perspectiva textocêntrica, é relevante sublinhar que, no trabalho de criação grupal, parece existir um consenso sobre as possibilidades autorais do ator. Na definição dada à criação coletiva por Pavis (2010), no seu texto A encenação contemporânea, isso se explica pela participação mais ativa dos atores na composição da peça: "trabalho que não está sob a direção exclusiva de um encenador, mas que deixa aos artistas, especialmente os atores, uma grande parte da decisão" (p. 415).

Santiago García (1988), mestre do teatro colombiano e porta-voz do movimento de criação coletiva do meu país, é enfático na hora de afirmar que esse tipo de abordagem demanda uma nova concepção do trabalho do ator. Nos processos de criação coletiva, “[...] o ator se apropria do espetáculo, não sendo alguém a serviço do espetáculo, mas um dos donos" (p. 118). Ele vai chamar de "promotor-criador" 
o novo tipo de ator que procura para o seu teatro e que compartilha a responsabilidade autoral e coletiva da peça teatral.

Além disso, García (2008) assinala, quando analisa os trabalhos de seu grupo, La Candelaria ${ }^{26}$, que neles a concepção tradicional de relações dos quatro elementos do teatro, cuja ordem seria autor, diretor, ator, espectador, fica altamente perturbada. Nesse panorama, a posição do dramaturgo como executante do texto (autor-texto) sofreria a transformação ator-texto (García, 2008).

Enquanto este projeto de pesquisa se propõe afinar a autonomia do ator como estratégia autoral, na criação coletiva de La Candelaria, o processo funciona ao contrário. Nas diferentes etapas de criação cênica, os quatro elementos mencionados ficam liberados da sua aparente autonomia. Vale a pena ressaltar que o espectador faz parte desse agrupamento de funções e, nessa relação entre obra e público, os artistas (diretores, atores ou escritores) tentam influir na formação de uma imagem teatral rica usando estratégias autorais (García, 2008).

Passando a outro estágio desse tipo de criação de grupo, agora indo para o Brasil e observando rapidamente algumas considerações feitas pela atriz e pesquisadora Miriam Rinaldi, do Teatro da Vertigem ${ }^{27}$, assinala-se que a autoria no processo colaborativo ${ }^{28}$ — procedimento bem diferente do da criação coletiva colombiana- se relaciona com a gênese dos materiais e com a forma como eles se processam e se transformam (Rinaldi, 2006). Embora o artigo escrito pela atriz parta da ideia de que a assinatura definitiva da autoria acaba ficando nas mãos

26 O teatro La Candelaria foi fundado em 1969 e é um dos mais importantes grupos de teatro da Colômbia. Sediado na capital desse país, Bogotá, é o grande promotor da criação coletiva nele.

27 O Teatro da Vertigem surgiu em 1991 e é referência obrigatória do chamado processo colaborativo no Brasil. O leitor entenderá que, ao se tratar de uma pesquisa feita por um ator colombiano no Brasil, tenha escolhido como exemplo de criação grupal um coletivo de cada país, dado que não se pretende um estudo aprofundado desse assunto.

28 As expressões criação coletiva e processo colaborativo produzem confusões constantemente. Nesta parte do capítulo, tomam-se dois casos que representam exemplos de ambas as possibilidades: La Candelaria (do lado da criação coletiva) e Teatro da Vertigem (como representante do processo colaborativo 
do escritor, deixa-se claro que ele não é o autor exclusivo da obra. "No processo colaborativo do teatro da Vertigem, a discussão da autoria não se liga exclusivamente à construção do texto escrito" (Rinaldi, 2006 , p. 135, itálico no original). Sobre a participação do ator na autoria da obra, Rinaldi (2006) afirma que "[c]onhecer a origem [dos] materiais, participar de sua produção e sua transformação, promover critérios de escolha são alguns procedimentos que fazem dos atores autores do trabalho" (p. 136).

Trate-se de criação coletiva ou processo colaborativo, no entanto a autoria da obra apresenta um problema de definição nesse tipo de produções porque fica sendo tanto grupal quanto particular, paradoxo que se elogia constantemente, mas que pouco tem sido estudado pelos teóricos. Em termos de atribuição, a prática real faz com que a necessidade de assinar a obra deixe a autoria no diretor (como no caso de La Candelaria) ou no escritor (no caso do Teatro da Vertigem). O reconhecimento das contribuições autorais dos atores, nesse panorama, não fica, no fim de contas, muito diferente dos processos mais tradicionais da encenação moderna.

A pergunta sobre que tipo de ator seria o desta pesquisa começa na indagação de algumas propostas que consideram a figura do ator além da interpretação, no sentido que foi apresentado acima. Os procedimentos associados às estruturas de grupo são fundamentais para iniciar o exercício. Mas, antes de começar com essa argumentação, gostaria de trazer as palavras de Gordon Craig que, no tom premonitório que o caracterizou, disse: “[h]oje eles [os atores] imitam e interpretam, amanhã eles deverão representar e interpretar e no terceiro dia eles deverão criar. Assim, o estilo retornará.” (2012, s/p., itálico no original).

brasileiro). O Dicionário do teatro brasileiro diferencia os dois conceitos e caracteriza o processo colaborativo como um processo contemporâneo de criação teatral, com raízes na criação coletiva (Guinsburg, Faria e Alves, 2006). Embora a criação coletiva, em termos históricos, seja anterior ao processo colaborativo, o segundo diferencia-se da primeira por ser um processo de criação no qual se propugna a autonomia e o aprofundamento das identidades criadoras da encenação (texto, cenário, figurino, entre outras). Na criação coletiva, essas identidades tendem a ser menos concretas e autônomas. 
Por estranho que pareça, trata-se do mesmo autor que propôs a supermarionete. Pois bem, é interessante como a grande mudança que fará renascer um estilo vaticina a passagem da interpretação a uma instância muito próxima do que este projeto aspira: a criação. Independentemente do preconceito que pode se perceber na fala de Craig —como se esses atores, por ser intérpretes, não criassem—, essa fala é fundamental para introduzir uma acepção que ganhou popularidade nos últimos anos: ator-criador.

Falando sobre tendências contemporâneas, Odete Aslan usa o termo ator-criador para se referir a uma noção, que ela reconhece ambígua, produto de uma nostalgia daquele que não pode criar um objeto artístico concreto (como o escritor, o pintor ou o compositor), mas ainda se considera artista (Aslan, 1979). Aslan (1979) define o ator-criador como aquele que se liberta da tirania do autor e das cadeias do encenador despótico. $\mathrm{O}$ uso daqueles termos dramáticos a leva até projetar o desejo de alguns atores de alcançar a figura do que ela chama de ator-rei. Tudo isso, no entanto, acaba sendo moderado quando conclui seu livro falando da ética de grupo como acontecimento contemporâneo.

Aslan não é muito clara nem aprofunda a questão ${ }^{29}$, mas sua fala mostra o reconhecimento da existência desse tipo de atores que insistem em se libertar dos papéis tradicionais aos quais quase sempre foi subalterno. Isso sempre ligado à questão de grupo.

Essa questão parece nortear as categorias que, como ator-criador, servem de contraponto ao ator-intérprete. Precisamente sobre essa linha, os pesquisadores brasileiros André Carreira e Daniel Oliveira da Silva escrevem um artigo (2006), que acaba sendo referência para outros autores, sobre algumas categorias que podem evidenciar os graus de autonomia que explicam diferentes experiências criativas de teatro de

29 O pesquisador brasileiro Matteo Bonfitto apresenta um conceito similar ao de Aslan. Ele fala de ator-compositor. Assim, parte da consideração do ator como criador para dirigir sua questão: “[...] o ator, para ser criador, precisa saber compor" (Bonfitto, 2009, p. XX). Seu conceito de materiais vai ser fundamental como ponto de partida do segundo capítulo deste livro. 
grupo. Para esse propósito, estudam os casos de alguns grupos que se inscrevem na categoria de processos colaborativos ou de criação coletiva.

$\mathrm{Na}$ pesquisa apresentada por esses autores, os depoimentos dos atores e diretores dos grupos consultados servem como insumos para pensar as categorias que definiriam essa participação mais ativa dos atores na autoria da encenação. No contexto do Teatro da Vertigem, aparecem, por exemplo, as combinações ator-criador, ator-dramaturgo, ator-encenador quase o tempo todo para falar das mesmas experiências ${ }^{30}$.

Os pesquisadores também assinalam a falta de bibliografia que dê conta dessas denominações (Carreira e Oliveira, 2006), o que, por um lado, dificulta a consolidação de categorias de análise; mas, por outro, demanda que nós, pesquisadores interessados no assunto, indaguemos mais a respeito disso. Os autores do artigo, no entanto, se esforçam por reduzir esse leque de possibilidades nominais a três instâncias: ator-criador, ator-autor e ator-encenador. Todas têm em comum o afastamento da noção do ator-intérprete, "que corresponderia a [sic] função menos dilatada do trabalho do ator, ocupando uma função ligada unicamente à interpretação" (Carreira e Oliveira, 2006, p. 7).

$\mathrm{O}$ ator-criador estaria mais associado ao processo colaborativo, dado que, apesar das contribuições dos atores, a assinatura final acaba sendo propriedade da direção e da dramaturgia; enquanto o ator-encenador estaria ligado a processos de criação coletiva em que as assinaturas individuais inexistem. Finalmente, a categoria de ator-autor ficaria como uma noção intermediária, não muito bem definida no artigo (Carreira e Oliveira, 2006).

30 Sobre o trabalho do ator no Teatro da Vertigem, a atriz e pesquisadora Miriam Rinaldi usa a expressão depoimento pessoal autoral para explicar os materiais de autoria do ator que são usados na companhia. A respeito disso, disse: "[h]á uma instância em que o ator do Teatro da Vertigem opera na exposição de seu 'eu', conjugando o material da pesquisa com sua visão pessoal e subjetiva. Nessa fase do trabalho é muito comum que o ator se posicione não pretendendo ser outra coisa senão "ele próprio" (Rinaldi, 2006, p. 140). 
Para fechar o artigo, os autores dizem que a autonomia do ator parece ser uma das bases para compreender essas noções e afirmam que a estrutura de grupo que começou a operar no Brasil na década de 1970 favorece a coautoria dos atores. Embora o texto não estabeleça uma posição profunda a respeito disso, é relevante o destaque feito à questão da autonomia do ator, no qual parecem coincidir com Aslan. A autonomia, levada à instância contrária à explorada por Carreira e Oliveira da Silva, então, será parte do que compõe os pressupostos contidos neste capítulo e que se discute na continuação.

\section{A solidão como caminho}

Chegamos ao ponto de início de uma consideração metodológica para abordar essa possibilidade de alcançar o estágio de ator-autor. Na estima do espetáculo unipessoal como espaço que potencializa a expressão de uma singularidade e entendendo que a autonomia do ator tem facilitado nos últimos anos a consideração de sua autoria na criação coletiva ou colaborativa, esta pesquisa fará uso do termo unipessoal e levará a questão da autonomia ao limite. Assim, o pressuposto que se debate nesta parte é a solidão como espaço criativo para o ator que procura fortalecer suas habilidades autorais.

Entende-se por solidão, no contexto desta pesquisa, a escolha do artista (o ator) do ato de trabalhar a partir de si mesmo com a intenção de fazer possível um processo de criação sem a intervenção de outras figuras que comandem as decisões do que será o produto cênico. No momento em que essas figuras (como o diretor, o dramaturgo, o cenógrafo ou o figurinista, entre outros) forem dispensadas no processo criativo, suas funções serão absorvidas pelo ator criador do espetáculo. Portanto, a palavra solidão não se entende aqui como é definida nos dicionários: "[e]stado de quem se acha ou vive só" (Ferreira, 2010, p. 708). Note-se que, na acepção do dicionário, aquele estado nada tem a ver com decisão, escolha ou opção consciente do sujeito. Por esse motivo, descartam-se as definições negativas do termo.

Também não se deve confundir a expressão que dá título a esta pesquisa - $\mathrm{O}$ ator em solidão- com a expressão ator solitário, pois 
não se trata de um assunto de isolamento e ausência de diálogo. Se fosse nesse sentido, esta pesquisa não procuraria produzir um espetáculo, nem contemplaria uma etapa de interação com o público. No capítulo que se ocupará de relatar o processo criativo do espetáculo unipessoal, voltarei a falar sobre a questão ao analisar como a criação cênica e autoral também é produto de diálogos com outros autores, criadores e de experiências compartilhadas com outros artistas de teatro, o que em nada tem por que renhir com a experiência de solidão na sala de ensaio. Será, então, uma solidão cheia de companhias. "Ah, quantos pensamentos indisciplinados e indiscretos no devaneio de um homem sozinho! Que companhia de seres sonhados num devaneio solitário!” (Bachelard, 2009, p. 78).

Pensando na solidão como instância criativa, o caminho dessa escolha acabou sendo iluminado pelas considerações do filósofo francês citado no final do parágrafo anterior: Gaston Bachelard. Em um momento no qual me perguntava sobre meu futuro como artista que enfrenta um projeto - este- que parecia ter mais detratores do que apoiadores, Bachelard apareceu para me dar a última força que necessitava. No ensaio intitulado "Fragmento de um diário do homem", Bachelard (1985), quase encerrando o primeiro parágrafo, afirma: “[n]a ordem do espírito, começar é ter a consciência do direito de recomeçar” (p. 190). Este projeto de pesquisa não se reduz só a um exercício acadêmico, como anunciei no começo deste capítulo, mas também constitui o começo de um projeto artístico. Nessa perspectiva, entendo-o como um recomeçar.

Nesse ensaio, Bachelard consegue transmitir o sentido de solidão que me interessa para assumir o processo criativo. $\mathrm{O}$ aspecto inicial que destaca o filósofo é a solidão como espaço apto para meditar. "A meditação solitária nos devolve à primitividade do mundo. Vale dizer que a solidão nos põe em estado de meditação primeira" (Bachelard, 1985, p. 193). Assim, “[p]ela solidão, a meditação tem toda a eficácia do espanto. A meditação primeira é, ao mesmo tempo, receptividade total e produtividade cosmologizante" (Bachelard, 1985, p. 193).

Esta última asseveração quebra a ideia preconcebida da solidão como isolamento. Ao contrário, a solidão se abre como espaço por excelência para estabelecer comunicação com o universo, porque, como 
diz o mesmo autor mais adiante em seu ensaio, "[a] solidão é necessária para nos desvincular dos ritmos ocasionais" e "[a]o nos colocar diante de nós mesmos, a solidão nos leva a falar conosco, a viver assim uma meditação ondulante que repercute por todas partes suas próprias contradições e que procura incessantemente uma síntese dialética íntima" (Bachelard, 1985, p. 199).

Até aqui, os pensamentos de Bachelard poderiam ser aplicados a qualquer experiência que exija uma instância meditativa. O filósofo ou o cientista poderiam tomar dessas reflexões elementos que atingem suas práticas. Contudo, o interesse desta pesquisa é conectar esse estado com a experiência artística. Bachelard já oferece respostas a essa premissa. Ele liga a solidão com o mundo da criação artística e prova que é um espaço mais que propício para esse objetivo. Nesse sentido, no livro A poética do devaneio, Bachelard relaciona a solidão com a criação poética. De fato, desde o começo do texto, o autor define que seu objeto de estudo será o devaneio poético.

O devaneio cósmico [...] é um fenômeno da solidão, um fenômeno que tem sua raiz na alma do sonhador. Não necessita de um deserto para estabelecer-se e crescer. Basta um pretexto - e não uma causa - para que nos ponhamos em "situação de solidão", em situação de solidão sonhadora. Nessa solidão, as próprias recordações se estabelecem como quadros. Os cenários dominam o drama. (Bachelard, 2009, p. 14)

Eis uma posição que justifica essa busca de uma situação de solidão. Do ponto de vista bachelardiano, ela aparece como terreno fértil para a criação, espaço próprio da poesia ${ }^{31}$. "Na solidão, basta que uma massa seja oferecida aos nossos dedos para que nos ponhamos a sonhar" (Bachelard, 2009, p. 162). Essa massa pode se traduzir como material artístico. Seja ela mármore, seja som, seja pigmento ou palavra, seja ação ou movimento, é na solidão que o sonhador

31 Mesmo que Bachelard estude o devaneio a partir da obra de diferentes poetas —entenda-se escritores de poesia-, o termo pode se aplicar no seu sentido de criação — poiesis_ e, portanto, aplicável aos interesses desta pesquisa. 
pode lhe dar forma. De fato, o filósofo associa a linguagem poética (criativa) com a linguagem da alquimia e esta última, particularmente, precisa ser aprendida na solidão (Bachelard, 2009). Além disso, Bachelard (2009) lhe atribui a condição de lugar revelador por excelência. "O devaneio faz-nos conhecer a linguagem sem censura. No devaneio solitário, podemos dizer tudo a nós mesmos" (p. 54). Essa ponderação é levada por Bachelard até considerar a solidão "o revelador fundamental do valor metafísico de toda sensibilidade humana" (1985, p. 198) e, em outros momentos, inclusive, conceder-lhe o valor de instância que resume a existência.

És retomado por uma antiga mágoa, retomas consciência de tua solidão humana, uma solidão que quer marcar, com um signo indelével, um ser que sabe mudar. Acreditavas sonhar - e recordas. Estás só. Foste só. Serás só. A solidão é tua duração. Tua solidão é tua própria morte que dura em tua vida, sob tua vida. (Bachelard, 1985, p. 196)

Assim, pois, a solidão, a partir da perspectiva de Bachelard, se constitui como espaço de encontro com o próprio ser íntimo, revelador de segredos e inspirador na atividade criativa. Em outro dos seus textos, o filósofo diz: "[n]a verdade, as paixões cozinham e recozinham na solidão. É encerrado em sua solidão que o ser de paixão prepara suas explosões ou seus feitos" (Bachelard, 1989, p. 29). Eu, como aquele ser de paixão, me reconheço nessa solidão bachelardinana e procuro nela meu espaço criativo.

Venho do país da criação coletiva. Na Colômbia, a história do teatro está profundamente ligada à necessidade de se agrupar. E esse fato é absolutamente político. Nosso teatro apareceu com força no contexto universitário, sindical e operário. Segundo a pesquisadora Beatriz J. Rizk (2008), a criação coletiva colombiana apostou no trabalho em grupo com a intenção de explorar formas de fazer inspiradas no modelo de estrutura socialista que caracterizava os discursos anti-establishment da época. Pensar no teatro colombiano é pensar em grupo. É esse meu legado, meu orgulhoso legado. No entanto, meu percurso me levou por outro caminho, o qual também constitui um ato 
político, não em relação às estruturas de poder, mas às formas estabelecidas que caracterizam as práticas de criação teatral na Colômbia.

Para apoiar essa afirmação, gostaria de colocar as palavras de outra pesquisadora latino-americana, Magaly Muguercia (2009), ao falar da prática no continente: “[...] estamos acostumados a pensar o político como consciência e discursividade opositoras a algum poder; mas hoje sabemos que existe uma política do ato íntimo e subversões que não se fazem com a consciência estruturada e nem sequer dentro da história" (p. 137). É nessa aposta pela construção de um espaço íntimo, unipessoal, da criação que sustento o caráter político do caminho que estou empreendendo. Decidir trabalhar em solidão quando se pertence ao mundo do teatro parece um contrassenso. Ainda mais quando se afirma que "[...] todas as pesquisas relativas à representação têm tido pelos menos uma coisa em comum: elas se definem como práticas coletivas" (Roubine, 1998, p. 202).

Mas, nem todas. Um exemplo relevante do contrário é o trabalho desenvolvido durante vários anos pela atriz brasileira Denise Stoklos. Por muito tempo, a atriz vem trabalhando na linha de um teatro próprio que ela chama de teatro essencial, no qual o ator é autor, diretor e coreógrafo de si mesmo (Stoklos, 2012, s/p.). Levando até as últimas consequências as possibilidades do espetáculo unipessoal e de sua autonomia artística, Stoklos descreve seu próprio trabalho como um exercício de autoconfiança e autossuficiência que se traduz "[n]a obstinação serena de que apenas a solidão assumida pode proporcionar ao criador de sua própria transformação a chance” (Stoklos, 1993, p. 17-18).

Reconhecida pela força de seu trabalho artístico, no qual apresenta um discurso altamente político que reflete sobre a sua condição de mulher, o questionamento do poder, das injustiças sociais, dos comportamentos padronizados e da estética e da ética do sistema capitalista, como ela mesma o expõe, afirma que a sua autonomia é libertária e profícua (Stoklos, 1993). Em consonância com os interesses desta pesquisa, ela elogia a solidão como espaço criativo.

Escrever, dirigir e atuar sozinha é solitário como qualquer processo criativo (como ao nascer e morrer?). Tem-se de estar só, pois se a 
orientação é à originalidade, não há modelos. Não há parâmetros conhecidos para conceber um trabalho que não esteja interessado em produzir a ideia de outro autor. Isso me levou a procurar estabelecer esse sistema que chamo de "Teatro Essencial”, e que compõe as bases desse trabalho para atuação, direção, texto e produção. (Stoklos, 1993, p. 50)

Note-se como ela se coloca no lugar de autora nesse seu depoimento. De sua perspectiva, não existe outro caminho diferente do da total autonomia para chegar a esse estágio. Em outro momento de seu livro Teatro essencial, relata a experiência da maternidade como aquilo que a levou ao que nomeia um "inadiável reencontro": suas possibilidades autorais (Stoklos, 1993, p. 28).

Como artista, sinto-me nesse mesmo lugar. No caso de Stoklos, reencontro; no meu, apenas encontro primeiro. Por isso, embora Stoklos apresente no seu texto uma linguagem bastante hermética que impossibilita entender as particularidades de seus métodos, suas afirmações são fundamentais para o cumprimento das minhas intenções artísticas e acadêmicas. Sua ideia de autonomia tem muito a ver com a do projeto $\mathrm{O}$ ator em solidão (na medida em que é considerada via privilegiada para o ator que não quer reproduzir as ideias de outros), assim como seu conceito de teatro essencial com o de ator-autor que aqui se procura (autor, diretor e coreógrafo de si mesmo).

Para conseguir o mesmo propósito de Stoklos, e tentando encontrar meus próprios procedimentos, estou fazendo uso do meu direito a me afastar da tradição que me formou como o ator que sou. Esse direito se traduz na consolidação de um espaço criativo em solidão, um lugar que me permita desenvolver minhas inquietações particulares, já não à sombra das particularidades de outros.

Jean-François Lyotard ampara minha decisão. Ele diz que todo ser humano tem direito ao no man's land, o que define como aquela segunda existência à qual qualquer um pode acessar para se encontrar e que pode ser entendida como o direito a permanecer separado, a não ter que responder aos outros (Lyotard, 1996). Definido como uma região secreta, Lyotard (1996) considera fundamental esse direito e afirma que ele deve ser reconhecido a todos os seres humanos e 
respeitado por todos eles. No meu caso, a solidão da sala de ensaio e minha autonomia para decidir sobre o conjunto artístico que comporá a obra ocupam aquele espaço. Isso dá uma qualidade particular à minha proposta, afastando-se de uma prática hierárquica que demanda a presença constante de observadores externos e que, tal como tem sido desenvolvida no meu caso, não me permitia a expressão das minhas inquietações.

Se o homem não preserva a região inumana onde pode encontrar-se com isto ou aquilo, que escape totalmente ao exercício dos direitos, não merece os direitos que the são reconhecidos. Por que teríamos direito à liberdade de expressão se não tivéssemos nada a dizer além do já dito? E como poder encontrar para dizer o que não sabemos dizer se não escutarmos absolutamente dentro de nós mesmos o silêncio do outro? Esse silêncio é uma exceção à reciprocidade dos direitos, mas é sua legitimação. Seria, de fato, necessário reconhecer a "segunda existência" seu direito absoluto, pois é ela que dá direito aos direitos. (Lyotard, 1996, p. 115)

Assim, a busca do ator em solidão não só se constitui como autonomia para a expressão de uma autoria; é também a busca de um espaço que preencha de conteúdos essa intenção. Talvez, espaço de receptividade total e produtividade cosmologizante, como propõe Bachelard. Finalmente, sou aquele sonhador de devaneios que busca ser autor da sua própria solidão (Bachelard, 2009), ator-autor no meu próprio devaneio, estado que Bachelard (2009) considera “promoção de ser” (p. 153).

\section{A expressão de uma inquietação particular}

Não posso fechar este capítulo sem fazer alusão a um fato que deu origem a este projeto de pesquisa. Mais do que um fato, é, na verdade, uma necessidade. $\mathrm{O}$ projeto $\mathrm{O}$ ator em solidão nasceu também, $\mathrm{e}$ principalmente, da necessidade de falar com nome próprio.

Como artista, existiam algumas inquietações que passavam constantemente pela minha mente e que, como ator, dificilmente poderia realizar. Particularmente, sempre tive a necessidade de falar sobre o 
assunto da homossexualidade. Os espetáculos que, no meu contexto, falavam do tema me pareciam superficiais e nunca encontrei algum tipo de afinidade com um diretor, nem espaço no meu grupo de teatro para desenvolver uma proposta nesse sentido, dado que o tema não era do interesse dos outros membros da equipe, e tudo o que se encenava era decidido a partir da voz da maioria.

Essa dicotomia entre o artista e o ator foi, por muito tempo, angustiante. Filho da tradição que descrevi acima, parecia que os únicos artistas da cena eram o diretor e o dramaturgo, entendendo que eles assinavam com seus nomes como o faria um pintor ou um compositor musical. De alguma maneira, o apresentado nas peças correspondia a suas visões do mundo. Como ator, me perguntava: e a minha?

A única maneira de conseguir colocar no palco a minha visão parecia me conduzir ao exercício da direção. No entanto, eu não queria renunciar ao meu ofício de ator. Essa palavra —ofício- foi fundamental para começar a resolver minhas angústias. Como ator, entendi que podia me deslocar em duas possibilidades: a do ofício e a do artista.

A primeira é a que mais claramente exerci até me perguntar pelo meu eu artista. Nesse sentido, considero que a relação entre atorintérprete e "ator de ofício" é bastante estreita. Durante os anos que trabalhei como ator nos grupos Íntimo Teatro e Teatro El Tablado, desenvolvi uma série de habilidades que fortaleceram meu ofício. A participação em várias montagens provenientes de tradições diversas foi uma verdadeira escola de treinamento das minhas ferramentas. $\mathrm{O}$ trabalho ao serviço da interpretação constitui a prática mais tradicional e reconhecida da formação de atores. Nesse sentido, tive grandes experiências no palco.

Contudo, continuava sem aparecer o ator-artista. Esse que não está aí só para interpretar as propostas de outros, mas que tem algo para dizer autonomamente. Segundo Luigi Pareyson (1997), "o fazer que não seja ao mesmo tempo um dizer não atinge a arte, mas permanece confinado no ofício" (p. 64). Baseado nas palavras de Pareyson, percebi-me como um ator que desenvolveu por muito tempo seu ofício, mas que deixou quieta sua necessidade de dizer, de falar com voz própria. 
Em um artigo intitulado $O$ ator contemporâneo: enfim, um artista?, o pesquisador Antônio Guedes (2011) reflete sobre a questão de considerar o ator como artista. Para conseguir esse propósito, parte da seguinte afirmação de Gordon Craig: "[a]tuar não é uma arte. Portanto, não é correto falar do ator como um artista" (citado por Guedes, 2011, p. 11). Posteriormente, Guedes contrapõe essa afirmação com outra de Craig, já apresentada acima. Aqui, cita-se a versão usada no artigo. "Hoje, o ator personifica e interpreta; amanhã, deverá representar e interpretar; no terceiro dia deverá criar. Desta forma, o estilo deverá retornar" (Craig citado por Guedes, 2011, p. 12). A partir desse contraponto e usando outras referências, entre elas Stanivlavski, Guedes se pergunta o que é que tem esse ator que cria e não mais interpreta, personifica ou representa ${ }^{32}$. As respostas que encontra em seu artigo se referem à problematização da mimese e não guardam aparentemente relação com os postulados desta pesquisa. Porém, em algum momento, parte da resposta que dá à questão de se o ator contemporâneo é artista apoia realmente o que se defende neste livro. "Ele [o ator] precisa abandonar o lugar de mediador entre um texto e o público; precisa deixar de ser um mero veículo destinado à transmissão de ideias para que finalmente se torne um artista" (Guedes, 2011, p. 13). De novo, a mudança implica o abandono dessa função ator-intérprete.

Nesse panorama, a possibilidade de falar com nome próprio como ator estaria representada, e aqui retomo Pareyson, por uma nova concepção do seu fazer. Assim, o ator que abandona sua função mediadora de discursos e assume o trabalho de expressar o próprio privilegiando sua visão do mundo poderia ser considerado artista: “[...] a tarefa do ator, do artista, é criar tendo como fundamento não mais um modelo, mas um conceito, um modo de ver" (Guedes, 2011, p. 15).

Esse artista que não abandona seu ofício de ator, mas que privilegia sua própria voz, é aquele que pretendo chamar de ator-autor.

32 Note-se como, em sintonia com Kantor, Craig também problematiza os termos interpretação e representação. 
Interessa-me chegar a essa categoria a partir da exploração das minhas próprias inquietações. Por isso, a peça que se encena levando em conta os pressupostos aqui colocados parte de referências que giram ao redor da pulsão homoerótica e da moralidade que a acompanha.

Como já foi dito, o projeto $O$ ator em solidão não se sustenta na atitude radical de rebeldia sem causa contra as figuras que comandam a tradição mais ortodoxa do fazer teatral (diretor e dramaturgo), embora apresente um ator emancipado. Quando falo em ator emancipado, parto da acepção mais clara do que significa o verbo emancipar. "Eximir(-se) do pátrio poder ou da tutela" (Ferreira, 2010, p. 275). Esse ator se liberta da tutela do dramaturgo e do encenador (esses nossos poderes pátrios) pelas suas necessidades artísticas em relação ao seu próprio dizer. Nesse sentido, não pode esperar que as respostas às suas inquietações sejam dadas por um encenador ou um autor diferente dele mesmo.

Voltando a Pareyson (1997), ele afirma que "[a] inseparabilidade de forma e conteúdo se resolve na coincidência do processo de formação do conteúdo com o de formação de matéria; mas esta coincidência aparece somente quando se esclarece, desde o início, que a arte é antes de tudo formação de matéria" (p. 65-66). Esse princípio de Pareyson somado à epígrafe que abre este capítulo resumem e justificam a concepção do espetáculo unipessoal como resposta à busca desse ator-autor. Tanto a forma do espetáculo quanto seu conteúdo nasceram da mesma ideia e não têm como ser separados. O ator em solidão não é só o nome de um projeto que sustenta a produção de um espetáculo unipessoal; é, além disso, o título de uma busca de expressão autônoma que não encontra outro meio para se materializar.

Considerado o problema desta pesquisa como problema artístico, não há outra resposta possível além da de criação de uma obra que dá a forma da pesquisa. A expressão daquela inquietação está intimamente ligada à construção dessa forma que representa o espetáculo unipessoal. Eis a potencialização da singularidade com que Ferracini define esse tipo de encenações. Continuando com Pareyson (1997): “[a] arte nasce no ponto em que não há outro modo de exprimir um conteúdo que o de formar uma matéria, e a formação de uma matéria só é arte quando ela própria é a expressão de um conteúdo" (p. 62). 
Para fechar este capítulo, basta dizer que o último dos meus pressupostos é o reconhecimento de uma necessidade de ir ao palco com a intenção de materializar minhas inquietações como artista sob uma perspectiva que privilegia minha visão do mundo. Para Pareyson (1997), o mundo do artista se materializa no:

[...] seu modo de pensar, viver e sentir, a sua concepção do mundo e seu posicionamento frente à vida, a sua Weltanschaunng e o seu ethos, as ideias, os pensamentos, os ideais, as aspirações que nutre no seu coração, as experiências, as escolhas, as crenças de que informa a sua vida, em suma, a sua personalidade concreta, toda a sua espiritualidade. (p. 57-58, itálico no original)

É isso o que pretendo levar à cena. Espiritualidade e visão do mundo podem muito bem definir o ser do artista, o que para Pareyson representa o conteúdo próprio da obra de arte: “[...] entre a espiritualidade do artista e o seu modo de formar há, precisamente, identidade, e assim a própria matéria formada é, de per si, conteúdo expresso" (Pareyson, 1997, p. 63, itálico no original).

Tanto a solidão como metodologia de trabalho na sala de ensaio quanto a solidão do palco como estratégia de emancipação do ator são a crença desse ator na possibilidade de fazer obra a partir da potencialização de suas qualidades autorais. Agindo como ator-artista e não só como ator de ofício, este projeto pretende, usando uma expressão de Pareyson, tornar a personalidade do artista energia formante.

Colocada sob o signo da arte, a personalidade do artista torna-se ela própria energia formante, vontade e iniciativa de arte, ou melhor, modo de formar, isto é, estilo. É o modo de formar, o modo de fazer arte, o modo de escolher e conectar as palavras, de configurar os sons, de traçar a linha ou de pincelar, em suma, o "gesto" do fazer, o "estilo", que introduz na obra toda a espiritualidade do artista e aí a entrega, de modo tão eloquente e definitivo, que a respeito da espiritualidade do autor é bem mais reveladora a sua obra do que qualquer documento ou confissão ou testemunho direto sobre sua vida, e com frequência é mais significativa a menor inflexão formal 
O ATOR EM SOLIDÃo

do que os próprios aspectos semânticos ou "referenciais" da obra, os argumentos dela e, às vezes, até os seus temas, que, de resto, são reveladores, significativos e expressivos enquanto elementos do próprio “estilo”. (Pareyson, 1997, p. 62, destaques no original)

Até aqui a apresentação dos meus pressupostos para o início deste caminho criativo. Vem, agora, o inventário dos materiais que me acompanharão nesta missão. 